\title{
Chemical Constituents from Andrographis echioides and Their Anti-Inflammatory Activity
}

De-Yang Shen ${ }^{1, \dagger}$, Shin-Hun Juang ${ }^{2, \dagger}$, Ping-Chung Kuo ${ }^{3, \dagger}$, Guan-Jhong Huang ${ }^{4}$, Yu-Yi Chan ${ }^{5}$, Amooru G. Damu ${ }^{1}$ and Tian-Shung $W u^{1,4,6, *}$

1 Department of Chemistry, National Cheng Kung University, Tainan 70101, Taiwan;

E-Mail: 13895113@mail.ncku.edu.tw (D.-Y.S.); agdamu@yogivemanauniversity.ac.in (A.G.D.)

2 Graduate Institute of Pharmaceutical Chemistry, China Medical University, No. 91, Hsueh-Shih Road, Taichung 40402, Taiwan; E-Mail: paul@mail.cmu.edu.tw

3 Department of Biotechnology, National Formosa University, Yunlin 632, Taiwan;

E-Mail: pcckuoo@sunws.nfu.edu.tw

4 Department of Pharmacy, China Medical University, Taichung 40402, Taiwan;

E-Mail: gjhuang@mail.cmu.edu.tw

5 Department of Biotechnology, Southern Taiwan University of Science and Technology, Tainan 71005, Taiwan; E-Mail: yuyichan@mail.stust.edu.tw

6 Chinese Medicine Research and Development Center, China Medical University Hospital, Taichung 40402, Taiwan

$\dagger$ These authors contributed equally to this work.

* Author to whom correspondence should be addressed; E-Mail: tswu@mail.ncku.edu.tw;

Tel.: +886-6-2757575 (ext. 65333); Fax: +886-6-2740552.

Received: 12 November 2012; in revised form: 11 December 2012 / Accepted: 17 December 2012 / Published: 27 December 2012

\begin{abstract}
Phytochemical investigation of the whole plants of Andrographis echioides afforded two new 2'-oxygenated flavonoids (1) and (2), two new phenyl glycosides (3) and (4), along with 37 known structures. The structures of new compounds were elucidated by spectral analysis and chemical transformation studies. Among the isolated compounds, (1-2) and (6-19) were subjected into the examination for their iNOS inhibitory bioactivity. The structure-activity relationships of the flavonoids for their inhibition of NO production were also discussed.
\end{abstract}


Keywords: Andrographis echioides; flavonoid; anti-inflammatory; iNOS

\section{Introduction}

Andrographis (Acanthaceae) is a genus of about 40 species, various members of which have a reputation in indigenous medicine. In traditional Indian medicine, several Andrographis species have been used in the treatment of dyspepsia, influenza, malaria and respiratory infections, and as astringent and antidote for poisonous stings of some insects [1,2]. More than 20 species of Andrographis have been reported to occur in India. The phytochemistry of this genus has been investigated quite well in view of its importance in Indian traditional medicine and reported to contain several flavonoids $[3,4]$ and labdane diterpenoids [5-10]. A. echioides, an annual herb occurring in South India, is listed in the Indian Materia Medica used as a remedy for fevers. However, information on the chemical composition and bioactivity of this species is very rare. There is only report of flavonoids as major components from the extracts of A. echioides in the previous literature [11-14]. As part of our program to study the bioactive constituents from Andrographis species [15,16], we have investigated the whole plant of $A$. echioides and four new compounds (1-4) were characterized. Herein, we wish to report on the structure elucidations of compounds $\mathbf{1 - 5}$ and the effects of flavonoids on NO inhibition in LPS-activated mouse peritoneal macrophages.

\section{Results and Discussion}

\subsection{Purification and Characterization}

The $85 \%$ aqueous $\mathrm{MeOH}$ extract of the whole plant of $A$. echioides was suspended in $\mathrm{H}_{2} \mathrm{O}$ and partitioned with $\mathrm{CHCl}_{3}$ to afford $\mathrm{CHCl}_{3}$ and $\mathrm{H}_{2} \mathrm{O}$ soluble layers, respectively. Each layer was subjected into purification by a combination of conventional chromatographic techniques to result in four new compounds (1-4). In addition, 37 known compounds were identified to be 2',6'-dihydroxyacetophenone 2'-O- $\beta$-D-glucopyranoside (5) [17], echioidinin 5-O- $\beta$-D-glucopyranoside (6) [15], echioidinin (7) [13], pinostrobin (8) [18], andrographidine C (9) [19], dihydroechioidinin (10) [13], tectochrysin 5-glucoside (11) [20], methyl salicylate glucoside (12) [21], 7,8-dimethoxy-5-hydroxyflavone (13) [22], 5,7,8-trimethoxyflavone (14) [23], skullcapflavone I 2'-methyl ether (15) [13], acetophenone-2-O- $\beta$-D-glucopyranoside (16) [24], androechin (17) [14], skullcapflavone I 2'-O- $\beta$-D-glucopyranoside (18) [13], tectochrysin (19) [25], 5,7,2'-trimethoxyflavone [26], echioidin [13], skullcapflavone I [27], 5,7-dimethoxyflavone [28], negletein 6-O-B-D-glucopyranoside [29], andrographidine E [19], 4-hydroxy-3-methoxy-trans-cinnamic acid methyl ester [30], 4-hydroxybenzaldehyde [31], 4-hydroxy-trans-cinnamic acid methyl ester [32], $O$-coumaric acid [33], 2,6-dihydroxybenzoic acid [34], $13^{2}$-hydroxy-(13 $\left.{ }^{2}-R\right)$-phaeophytin [35], (E)-phytyl-epoxide [36], phytol [37], phytene 1,2-diol [38], (+)-dehydrovomifoliol [39], $3 \beta$-hydroxy-5 $\alpha, 6 \alpha$,-epoxy-7-megastigmen-9-one $\quad[40], \quad \beta$-sitosterol [41], $\beta$-sitosteryl-3-O- $\beta$-glucopyranoside [42], squalene [43], $1 H$-indole-3-carbaldehyde [44], and loliolide [45] by comparison of their physical and spectral data with those reported in the literature. 
Table 1. ${ }^{1} \mathrm{H}$ and ${ }^{13} \mathrm{C}$ NMR data of compounds $\mathbf{1}$ and $2{ }^{\mathrm{a}}$ in DMSO- $d_{6}$.

\begin{tabular}{|c|c|c|c|c|}
\hline & \multicolumn{2}{|l|}{1} & \multicolumn{2}{|l|}{2} \\
\hline Position & $\delta_{\mathrm{H}}(J, \mathrm{~Hz})$ & $\delta_{\mathrm{C}}$ & $\delta_{\mathrm{H}}(J, \mathrm{~Hz})$ & $\delta_{\mathrm{C}}$ \\
\hline 2 & & 159.1 & $5.70, \mathrm{dd}(12.5,3.0)$ & 74.2 \\
\hline \multirow[t]{2}{*}{3} & $7.05, \mathrm{~s}$ & 111.5 & $2.64, \mathrm{dd}(16.0,3.0)$ & 43.9 \\
\hline & & & $3.04, \mathrm{dd}(16.0,12.5)$ & \\
\hline 4 & & 178.3 & & 189.6 \\
\hline 5 & & 149.5 & & 159.7 \\
\hline 6 & $7.17, \mathrm{~s}$ & 102.1 & $6.46, \mathrm{~d}(2.5)$ & 97.7 \\
\hline 7 & & 151.6 & & 165.4 \\
\hline 8 & & 130.9 & $6.32, \mathrm{~d}(2.5)$ & 95.9 \\
\hline 9 & & 146.1 & & 164.3 \\
\hline 10 & & 109.5 & & 106.3 \\
\hline $1^{\prime}$ & & 117.1 & & 125.0 \\
\hline $2^{\prime}$ & & 156.8 & & 154.3 \\
\hline $3^{\prime}$ & 7.04, d (8.0) & 117.1 & $6.85, \mathrm{~d}(6.5)$ & 115.6 \\
\hline $4^{\prime}$ & $7.38, \mathrm{dd}(8.0,8.0)$ & 132.7 & $7.17, \mathrm{dd}(6.5,6.5)$ & 129.4 \\
\hline $5^{\prime}$ & 6.99, ddd $(8.0,8.0,1.6)$ & 119.6 & $6.84, \mathrm{dd}(6.5,6.5)$ & 119.2 \\
\hline $6^{\prime}$ & $8.00, \mathrm{dd}(8.0,1.6)$ & 128.7 & $7.41, \mathrm{~d}(6.5)$ & 126.9 \\
\hline $1 "$ & $4.60, \mathrm{~d}(7.6)$ & 105.5 & $4.83, \mathrm{~d}(7.5)$ & 101.9 \\
\hline $2^{\prime \prime}$ & $3.27-3.37, \mathrm{~m}$ & 73.8 & $3.26-3.43, \mathrm{~m}$ & 73.5 \\
\hline $3 "$ & $3.27-3.37, \mathrm{~m}$ & 77.8 & $3.15, \mathrm{~m}$ & 76.4 \\
\hline $4 "$ & $3.13, \mathrm{~m}$ & 70.4 & $3.26-3.43, \mathrm{~m}$ & 70.0 \\
\hline $5^{\prime \prime}$ & $3.27-3.37, \mathrm{~m}$ & 76.1 & $3.26-3.43, \mathrm{~m}$ & 77.6 \\
\hline \multirow[t]{2}{*}{$6 "$} & $3.46, \mathrm{~m}$ & 61.3 & $3.26-3.43, \mathrm{~m}$ & 61.0 \\
\hline & $3.73, \mathrm{~m}$ & & $3.64, \mathrm{~m}$ & \\
\hline $\mathrm{OH}-2^{\prime b}$ & 10.75, br s & & 9.80, br s & \\
\hline $\mathrm{OH}-8^{\mathrm{b}}$ & 9.30, br s & & & \\
\hline $\mathrm{OCH}_{3}-7$ & $3.90, \mathrm{~s}$ & 56.3 & $3.79, \mathrm{~s}$ & 55.9 \\
\hline
\end{tabular}

\subsection{Structural Elucidation of Compounds 1-5}

Compound 1 was obtained as optically active white amorphous powder. The HRFABMS of 1 showed a molecular ion peak at $m / z 462.1159$ corresponding to the molecular formula $\mathrm{C}_{22} \mathrm{H}_{22} \mathrm{O}_{11}$ and was also corroborated by ${ }^{13} \mathrm{C}$ NMR spectrum (Table 1) which displayed 22 carbon signals. A fragment ion at $m / z 301[(\mathrm{M}-162)+\mathrm{H}]^{+}$observed in the FAB-MS spectrum was the indication of the presence for an $O$-glycosidic hexose moiety. It was also confirmed by $m / z 299[(\mathrm{M}-162)-\mathrm{H}]^{-}$observed in the negative ESI LC/MS/MS (Figure 1). The UV spectrum exhibited absorption maxima at 271 and $328 \mathrm{~nm}$ was typical of the occurrence for the basic skeleton of flavone with 5,7,8-trioxygenation [46]. Addition of sodium acetate did not cause any change in the absorption maximum band II and it suggested the absence of free hydroxyl at C-7. The IR spectrum of $\mathbf{1}$ showed a hydroxyl absorption band at $3368 \mathrm{~cm}^{-1}$ and a carbonyl absorption band at $1628 \mathrm{~cm}^{-1}$, respectively. In the ${ }^{1} \mathrm{H}$ NMR spectrum 
(Table 1) of $\mathbf{1}$, there were two broad singlets at $\delta 10.75$ and 9.30 exchangeable with $\mathrm{D}_{2} \mathrm{O}$ to be assigned as non-chelated hydroxyl groups at C-2' and C-8. It also displayed the characteristic aromatic proton signals at $\delta 8.00,7.38,7.04$ and 6.99 corresponding for a 2'-oxygenated ring B pattern [19] which was assigned to the H-6', H-4', H-3', and H-5', respectively. Two sharp singlets at $\delta 7.17$ and 7.05 were attributed to H-6 and H-3 [47], since the ${ }^{2} J,{ }^{3} J$-correlations from H-6 to C-5, C-7, C-8 and C-10 and from $\mathrm{H}-3$ to $\mathrm{C}-2, \mathrm{C}-4$, and $\mathrm{C}-1$ ', respectively, were exhibited in the HMBC spectrum (Figure 2). In addition, a methoxy signal at $\delta 3.90(\mathrm{~s})$ which displayed $\mathrm{HMBC}$ correlation with $\mathrm{C}-7$ was located at C-7. An anomeric proton signal at $\delta 4.60(\mathrm{~d}, 1 \mathrm{H}, J=7.6 \mathrm{~Hz})$ suggested the presence of a sugar residue with $\beta$-configuration. With the aid of ${ }^{13} \mathrm{C}$ NMR spectral analysis, six carbon signals at $\delta 105.5,77.8$, $76.1,73.8,70.4$, and 61.3 were identified as D-glucose. The glucose residue in $\mathbf{1}$ was found to be linked to C-5 since a NOE cross-peak was observed between H-1" and H-6 in its ROESY spectrum and a ${ }^{3} J$-correlation between H-1" and C-5 was also displayed in its HMBC spectrum (Figure 2). Acid hydrolysis of $\mathbf{1}$ with $2 \mathrm{~N} \mathrm{HCl}$ afforded glucose and an aglycone identified as 2',5,8-trihydroxy-7-methoxyflavone [48]. On the basis of the above spectral evidences, the structure of 1 was established as 5,8,2'-trihydroxy-7-methoxyflavone-5-O- $\beta$-D-glucopyranoside, and given the trivial name as androgechoside $\mathrm{A}$.

Figure 1. (A) Structure of 1 and main fragments under LC/MS/MS (negative ESI); (B) $\mathrm{LC} / \mathrm{MS} / \mathrm{MS}$ spectrum.

(A)

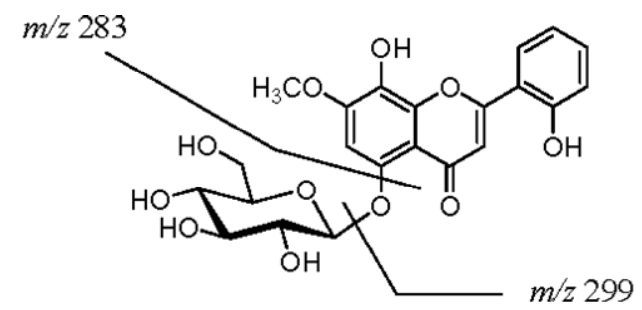

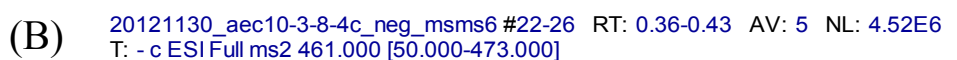

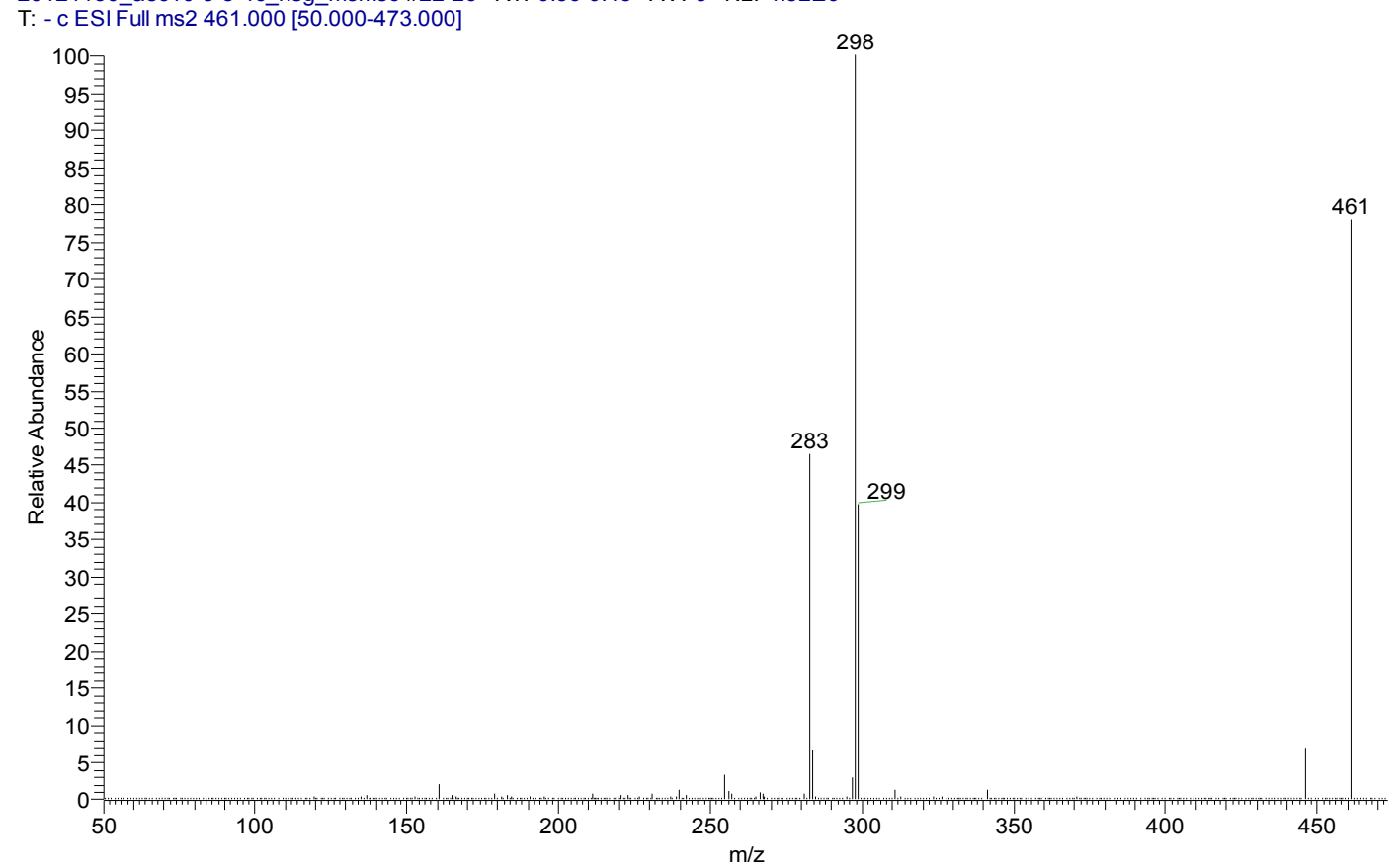


Figure 2. Selected HMBC $(\rightarrow)$ and NOESY $(\leftrightarrow)$ spectrum for compounds 1-5.

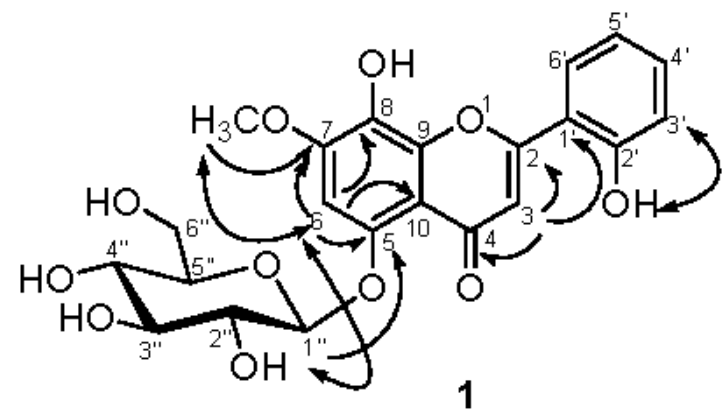

1

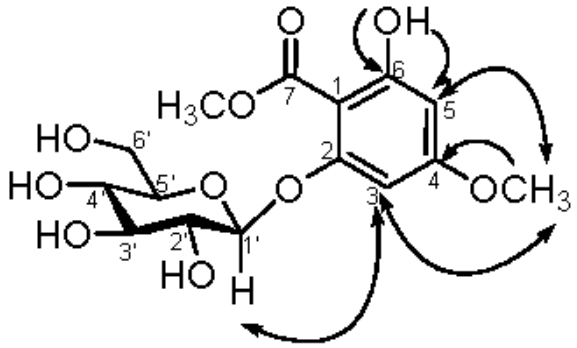

3

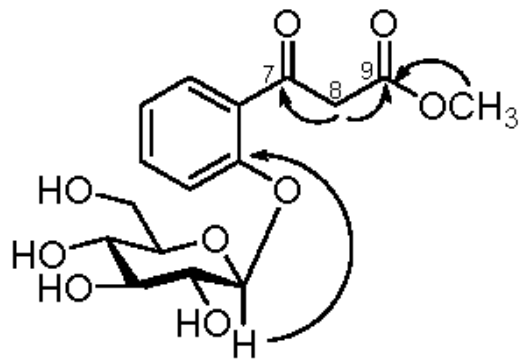

4

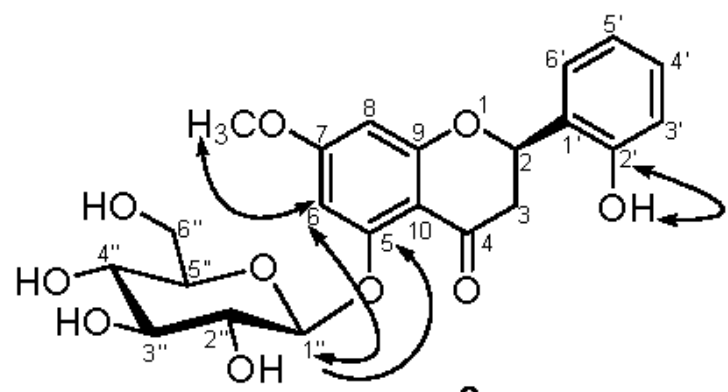

2

Compound 2 was purified as optically active white amorphous powder with elemental composition $\mathrm{C}_{22} \mathrm{H}_{24} \mathrm{O}_{10}$ from its HRFABMS data $\left(\mathrm{m} / z\right.$ 449.1449 $\left.[\mathrm{M}+\mathrm{H}]^{+}\right)$. A fragment ion at $\mathrm{m} / z \quad 285$ $[(\mathrm{M}-162)-\mathrm{H}]^{-}$observed in the negative ESI MS/MS spectrum (Figure 3) was the indication of the presence for an $O$-glycosidic hexose moiety. The IR spectrum exhibited absorption bands at 3373 and $1609 \mathrm{~cm}^{-1}$ characteristic for the hydroxyl and conjugated carbonyl groups, respectively, together with the UV absorption maximum at $280 \mathrm{~nm}$, suggested the presence of a flavanone skeleton [49]. The UV absorption maximum unaffected by the addition of NaOAc indicated the absence of free hydroxyls at C-7 and C-5 positions. The ${ }^{1} \mathrm{H}$ NMR spectrum (Table 1) of 2 exhibited a broad singlet at $\delta 9.80$ exchangeable with $\mathrm{D}_{2} \mathrm{O}$ attributed to a non-chelated hydroxyl group at $\mathrm{C}-2^{\prime}$ as it showed long range HMBC correlations with these carbons at C-1' $(\delta 125.0)$ and C-2' $(\delta 154.3)$ (Figure 2). A typical $\mathrm{ABCD}$ coupled system at $\delta 6.85,7.17,6.84$ and 7.41 established the presence of four adjacent aromatic protons (H-3', H-4', H-5' and H-6') in ring B and also supported the presence of OH-2'. In addition, two meta coupled aromatic doublets at $\delta 6.32(J=2.5 \mathrm{~Hz})$ and $6.46(\mathrm{~J}=2.5 \mathrm{~Hz})$ attributed for H-8 and H-6, respectively, suggested that compound $\mathbf{2}$ possessed flavanone basic skeleton. In the upfield region, three sets of doublets of doublets at $\delta 5.70(1 \mathrm{H}, \mathrm{dd}, J=12.5,3.0 \mathrm{~Hz})$, $3.04(1 \mathrm{H}, \mathrm{dd}, J=16.0,12.5 \mathrm{~Hz})$ and $2.64(1 \mathrm{H}, \mathrm{dd}, J=16.0,3.0 \mathrm{~Hz})$ which were characteristic signals of $\mathrm{H}-2, \mathrm{H}-3_{\mathrm{eq}}$ and $\mathrm{H}-3_{\mathrm{ax}}$ of flavanone also supported this suggestion. Moreover, a methoxy signal at $\delta 3.79$ (s) which displayed NOESY correlations with H-6 and H-8 was deduced to be located at C-7. The appearance of one glucose moiety in 2 was revealed by the proton signals at $\delta 4.83(1 \mathrm{H}, \mathrm{d}$, $J=7.5 \mathrm{~Hz})$ and $3.26-3.43(5 \mathrm{H}, \mathrm{m})$, and the carbon resonances at $\delta 101.9,77.6,76.4,73.5,70.0$, and 61.0 [50]. The glucose should attach at C-5 as $\beta$-configuration, which were identified by the coupling constant of the anomeric proton and the ${ }^{3} J$-HMBC correlation between H-1" $(\delta 4.83)$ and C-5 $(\delta 159.7)$ (Figure 2). The location of $\beta$-glucose was further confirmed through the NOE crosspeak between H-1" and H-6. The circular dichroism (CD) spectrum of $\mathbf{2}$ showed a negative Cotton effect at $337 \mathrm{~nm}$ and a positive Cotton effect at $275 \mathrm{~nm}$, suggesting the absolute configuration at C-2 to be $R$ [51]. On the 
basis of the foregoing studies, the structure of $\mathbf{2}$ was determined as (2R)-5,2'-dihydroxy-7methoxyflavanone-5-O- $\beta$-D-glucopyranoside and trivially named as androgechoside $\mathrm{B}$.

Figure 3. (A) Structure of 2 and main fragments under LC/MS/MS (negative ESI); (B) LC/MS/MS spectrum.

(A)

$m / z 139$

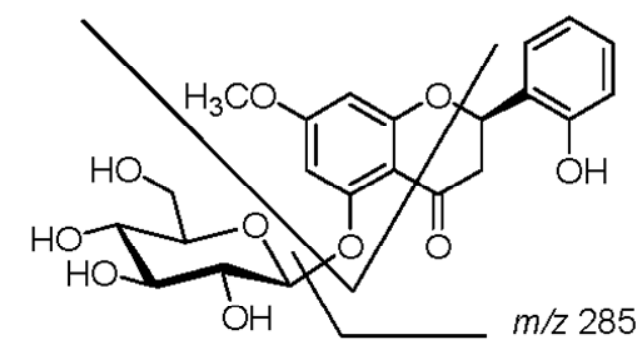

(B)

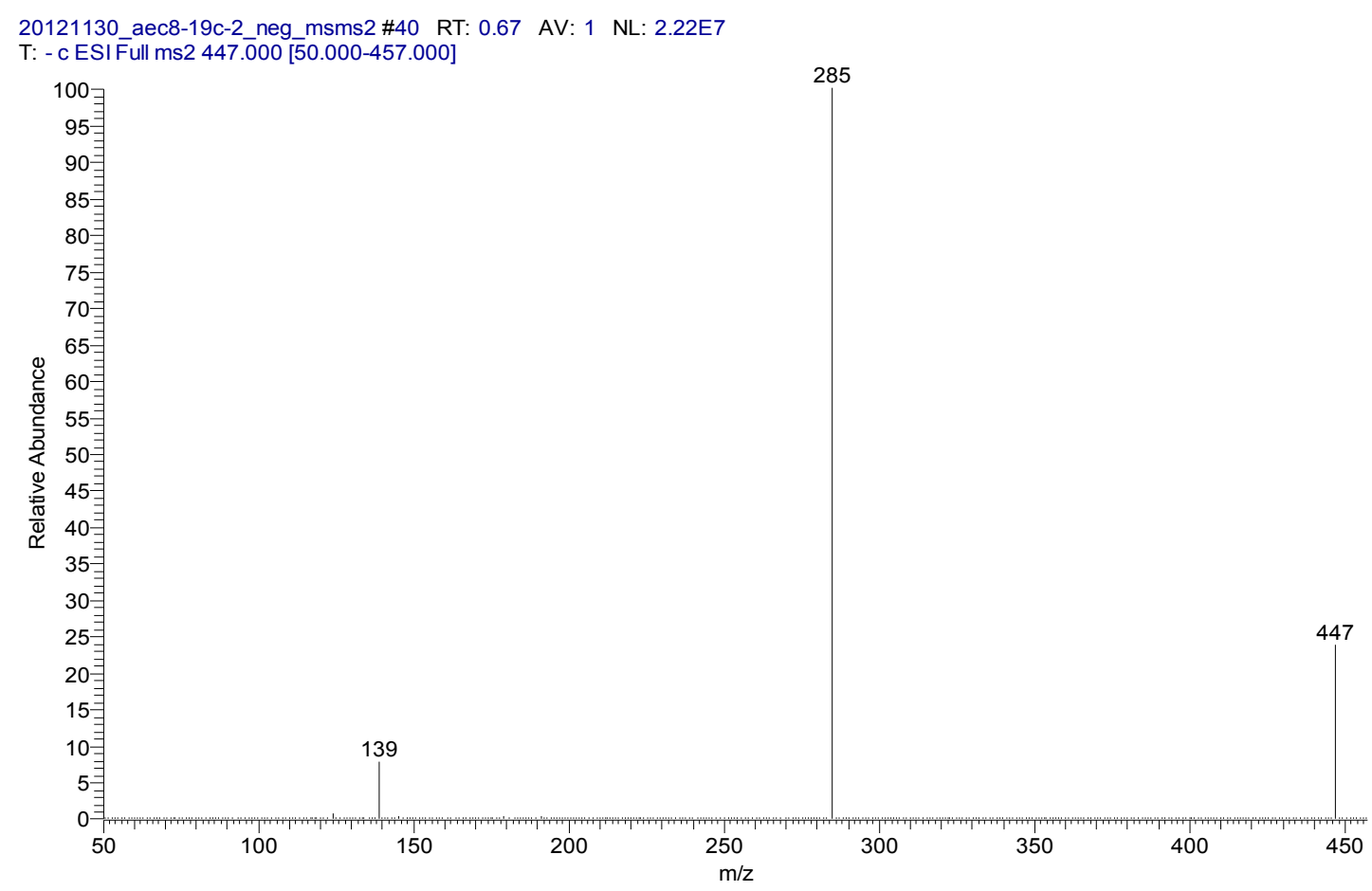

Compound 3 was obtained as an optically active white amorphous powder. Its molecular formula, $\mathrm{C}_{15} \mathrm{H}_{20} \mathrm{O}_{10}$, was established on the basis of HRESIMS $\left(\mathrm{m} / \mathrm{z} 383.0952[\mathrm{M}+\mathrm{Na}]^{+}\right.$, calcd 383.0954). A fragment ion at $m / z 197[(\mathrm{M}-162)-\mathrm{H}]^{-}$observed in the negative ESI MS/MS spectrum (Figure 4). The IR spectrum of 3 sh Darmstadt owed absorption bands for hydroxyl and carbonyl groups at 3449 and $1652 \mathrm{~cm}^{-1}$. The ${ }^{1} \mathrm{H}$ NMR spectrum (Table 2) of $\mathbf{3}$ displayed an intramolecular hydrogen bonding proton signal at $\delta 11.4(\mathrm{~s})$, two meta coupled aromatic protons at $\delta 6.14(\mathrm{~d}, J=2.4 \mathrm{~Hz})$ and $6.36(\mathrm{~d}$, $J=2.4 \mathrm{~Hz}$ ), and two methoxy groups at $\delta 3.81$ (s) and $3.88(\mathrm{~s})$, respectively. In addition, the proton signals for an anomeric proton at $\delta 4.96(\mathrm{~d}, J=7.6 \mathrm{~Hz})$, oxygenated methylene at $\delta 3.91(1 \mathrm{H}, \mathrm{m})$ and $3.69(1 \mathrm{H}, \mathrm{m})$, and oxygenated methines at $\delta 3.60-3.40(4 \mathrm{H}, \mathrm{m})$ suggested the presence of one sugar moiety. In the ${ }^{13} \mathrm{C}$ NMR spectrum (Table 2 ) of $\mathbf{3}$, the carbon resonances at $\delta 102.5,74.7,77.7,71.2$, 78.0, 62.6 [50] further confirmed that 3 was substituted with one glucose. Moreover, in the ${ }^{13} \mathrm{C}$ NMR spectrum six characteristic aromatic carbons at $\delta 166.1,165.2,161.0,98.5,96.1$ and 95.4 indicated the 
occurrence of an unsymmetrically substituted phloroglucinol unit [52]. Acid hydrolysis of $\mathbf{3}$ produced D-glucose and its absolute configuration was determined by HPLC method. The relative locations of the methyl ester, hydroxyl, methoxy group and sugar moieties were established from HMBC spectrum (Figure 2), in which correlations of the methoxy group $(\delta 3.81)$ with $\mathrm{C}-4$ ( $\delta 166.1)$, the hydroxyl group $(\delta$ 11.4) with C-6 ( $\delta$ 165.2) and C-5 ( $\delta$ 96.1) were observed. The location of sugar unit was assigned by an NOESY experiment, in which NOESY correlation was found between $\delta 4.96(1 \mathrm{H}, \mathrm{d}, J=7.6 \mathrm{~Hz})$ and $\delta 6.36(1 \mathrm{H}, \mathrm{d}, J=2.4 \mathrm{~Hz})$, indicating that the glucose was attached at C-2 through oxygen atom. Thus, the structure of compound $\mathbf{3}$ was determined as 2-O- $\beta$-D-glucopyranosyl-4-methoxy-2,4, 6-trihydroxybenzoate and named trivially as androechioside A.

Figure 4. (A) Structure of 3 and main fragments under LC/MS/MS (negative ESI); (B) LC/MS/MS spectrum.

(A)

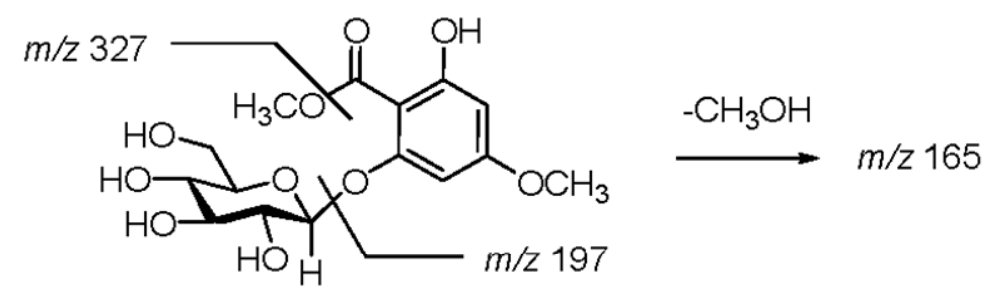

(B)

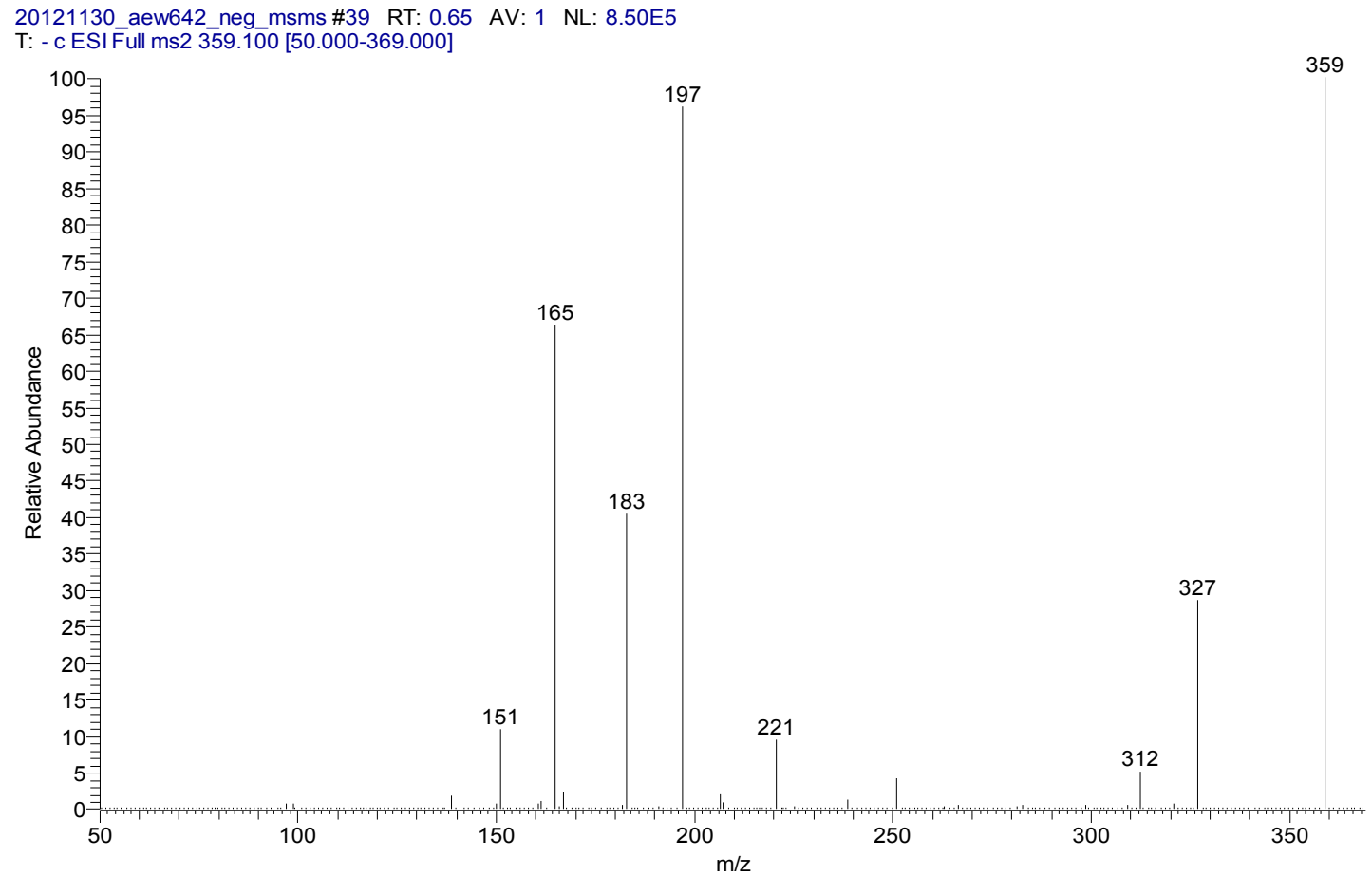


Table 2. ${ }^{1} \mathrm{H}$ and ${ }^{13} \mathrm{C}$ NMR Data for $3-5$ in acetone- $d_{6}$.

\begin{tabular}{cccclcl}
\hline \multirow{2}{*}{ Position } & \multicolumn{3}{c}{$\mathbf{3}^{\mathrm{a}}$} & \multicolumn{1}{c}{$\mathbf{4}^{\mathrm{b}}$} & \multicolumn{1}{c}{$\mathbf{5}^{\mathrm{a}}$} \\
\cline { 2 - 6 } & $\delta_{\mathrm{C}}$ & $\delta_{\mathrm{H}}$ mult $(J, \mathrm{~Hz})$ & $\delta_{\mathrm{C}}$ & $\delta_{\mathrm{H}}$ mult $(J, \mathrm{~Hz})$ & $\delta_{\mathrm{C}}$ & $\delta_{\mathrm{H}}$ mult $(J, \mathrm{~Hz})$ \\
\hline 1 & 98.5 & & 127.3 & & 111.8 & \\
2 & 161.0 & & 156.9 & & 159.5 & \\
3 & 95.4 & $6.36, \mathrm{~d}(2.4)$ & 116.0 & $7.33, \mathrm{~d}(7.8)$ & 105.3 & $6.75, \mathrm{dd}(8.4,1.2)$ \\
4 & 166.1 & & 134.3 & $7.54, \mathrm{dd}(7.8,7.8)$ & 136.1 & $7.38, \mathrm{dd}(8.4,8.4)$ \\
5 & 96.1 & $6.14, \mathrm{~d}(2.4)$ & 122.0 & $7.12, \mathrm{dd}(7.8,7.8)$ & 111.2 & $6.55, \mathrm{dd}(8.4,1.2)$ \\
6 & 165.2 & & 129.9 & $7.75, \mathrm{~d}(7.8)$ & 163.8 & \\
7 & 171.7 & & 193.7 & & 205.0 & \\
8 & & & 49.8 & $4.23, \mathrm{~d}(16.4)$ & 33.8 & $2.77, \mathrm{~s}$ \\
& & & $4.07, \mathrm{~d}(16.4)$ & & \\
9 & & & 168.5 & & & \\
$1^{\prime}$ & 102.5 & $4.96, \mathrm{~d}(7.6)$ & 101.1 & $5.15, \mathrm{~d}(7.2)$ & 101.2 & $5.12, \mathrm{~d}(8.8)$ \\
$2^{\prime}$ & 74.7 & $3.60-3.40, \mathrm{~m}$ & 73.4 & $3.60-3.40, \mathrm{~m}$ & 73.6 & $3.59, \mathrm{dd}(8.8,8.8)$ \\
$3^{\prime}$ & 77.7 & $3.60-3.40, \mathrm{~m}$ & 77.0 & $3.60-3.40, \mathrm{~m}$ & 77.3 & $3.46, \mathrm{dd}(8.8,8.8)$ \\
$4^{\prime}$ & 71.2 & $3.60-3.40, \mathrm{~m}$ & 70.1 & $3.60-3.40, \mathrm{~m}$ & 70.2 & $3.54, \mathrm{dd}(8.8,8.8)$ \\
$5^{\prime}$ & 78.0 & $3.60-3.40, \mathrm{~m}$ & 77.0 & $3.60-3.40, \mathrm{~m}$ & 77.1 & $3.55, \mathrm{~m}$ \\
$6^{\prime} \mathrm{a}$ & 62.6 & $3.91, \mathrm{~m}$ & 61.4 & $3.87, \mathrm{~m}$ & 61.6 & $3.88, \mathrm{dd}(12.0,2.0)$ \\
$6^{\prime} \mathrm{b}$ & & $3.69, \mathrm{~m}$ & & $3.72, \mathrm{~m}$ & & $3.70, \mathrm{dd}(12.0,5.2)$ \\
$\mathrm{OCH}_{3}-4$ & 55.9 & $3.81, \mathrm{~s}$ & & & & \\
$\mathrm{OCH}_{3}-7$ & 52.5 & $3.88, \mathrm{~s}$ & & & & \\
$\mathrm{OCH}_{3}-9$ & & & 51.1 & $3.66, \mathrm{~s}$ & & $13.0, \mathrm{br} \mathrm{s}$ \\
$\mathrm{OH}^{\prime} 6$ & & $11.4, \mathrm{~s}$ & & & & \\
\hline
\end{tabular}

${ }^{\text {a }}$ Data were measured at $400 \mathrm{MHz}\left({ }^{1} \mathrm{H}\right)$ and $125\left({ }^{13} \mathrm{C}\right) ;{ }^{b}$ Data were and in $300 \mathrm{MHz}\left({ }^{1} \mathrm{H}\right)$ and $75 \mathrm{MHz}\left({ }^{13} \mathrm{C}\right)$.

Compound 4 was purified as optically active white amorphous powder and the molecular formula was determined as $\mathrm{C}_{16} \mathrm{H}_{20} \mathrm{O}_{9}$ by HR-ESI mass spectrometric analysis. A fragment ion at $\mathrm{m} / z 193$ $[(\mathrm{M}-162)-\mathrm{H}]^{-}$observed in the negative ESI MS/MS spectrum (Figure 5). The IR spectrum showed hydroxyl, ester, and carbonyl groups at 3381, 1731, and $1672 \mathrm{~cm}^{-1}$, respectively. The ${ }^{1} \mathrm{H}$ NMR spectroscopic data (Table 2) showed the characteristic of 1,2-disubstituted aromatic ring system from the chemical shifts at $\delta 7.12(1 \mathrm{H}, \mathrm{dd}, J=7.8,7.8 \mathrm{~Hz}), 7.33(1 \mathrm{H}, \mathrm{d}, J=7.8 \mathrm{~Hz}), 7.54(1 \mathrm{H}, \mathrm{dd}, J=7.8$, $7.8 \mathrm{~Hz})$, and $7.75(1 \mathrm{H}, \mathrm{d}, J=7.8 \mathrm{~Hz})$. It also showed that the compound had a methyl ester at $\delta 3.66$ $(3 \mathrm{H}, \mathrm{s})$, and suggested a $\beta$-keto ester structure for it with an unsubstituted $\alpha$-methylene group $[\delta 4.23$ $(1 \mathrm{H}, \mathrm{d}, J=16.4 \mathrm{~Hz})$ and $4.07(1 \mathrm{H}, \mathrm{d}, J=16.4 \mathrm{~Hz})]$. Furthermore, the ${ }^{1} \mathrm{H}$ and ${ }^{13} \mathrm{C}$ NMR spectroscopic data (Table 2) showed the presence of a $\beta$-glucopyranosyl unit including the anomeric proton signal at $\delta 5.15(1 \mathrm{H}, \mathrm{d}, J=7.2 \mathrm{~Hz})$ and the carbon signals at $\delta 101.1,77.0,77.0,73.4,70.1$ and 61.4 , in addition to the signals of the aglycone moiety. The location of sugar unit was assigned by an NOESY experiment, in which NOESY correlation was found between $\mathrm{H}-1^{\prime}(\delta 5.15)$ and $\mathrm{H}-3(\delta$ 7.33), indicating that the glucose was attached at C-2. Moreover, HMBC spectrum (Figure 2) further confirmed the linkage of sugar unit from the ${ }^{3} J$-correlation between H-1' $(\delta 5.15)$ and C-2 ( $\left.\delta 156.9\right)$. Therefore, the chemical structure of $\mathbf{4}$ was elucidated as methyl 3-(2-hydroxyphenyl)-3-oxopropanoate $2-O-\beta$-D-glucopyranoside and named trivially as androechioside $\mathrm{B}$ following the convention. 
Figure 5. (A) Structure of 4 and main fragments under LC/MS/MS (negative ESI); (B) LC/MS/MS spectrum.

(A)

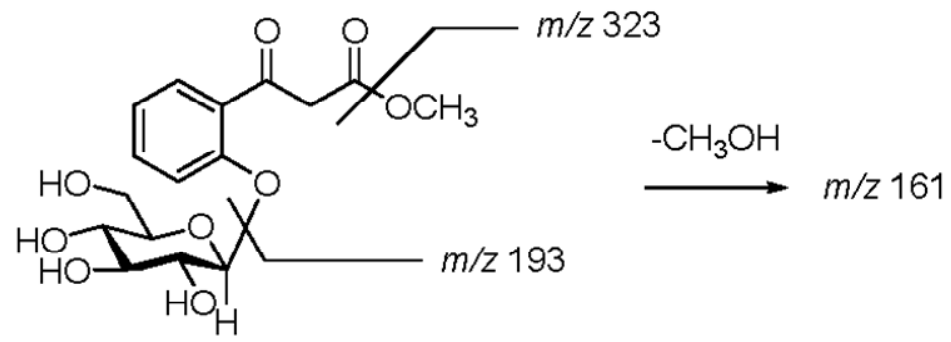

(B)

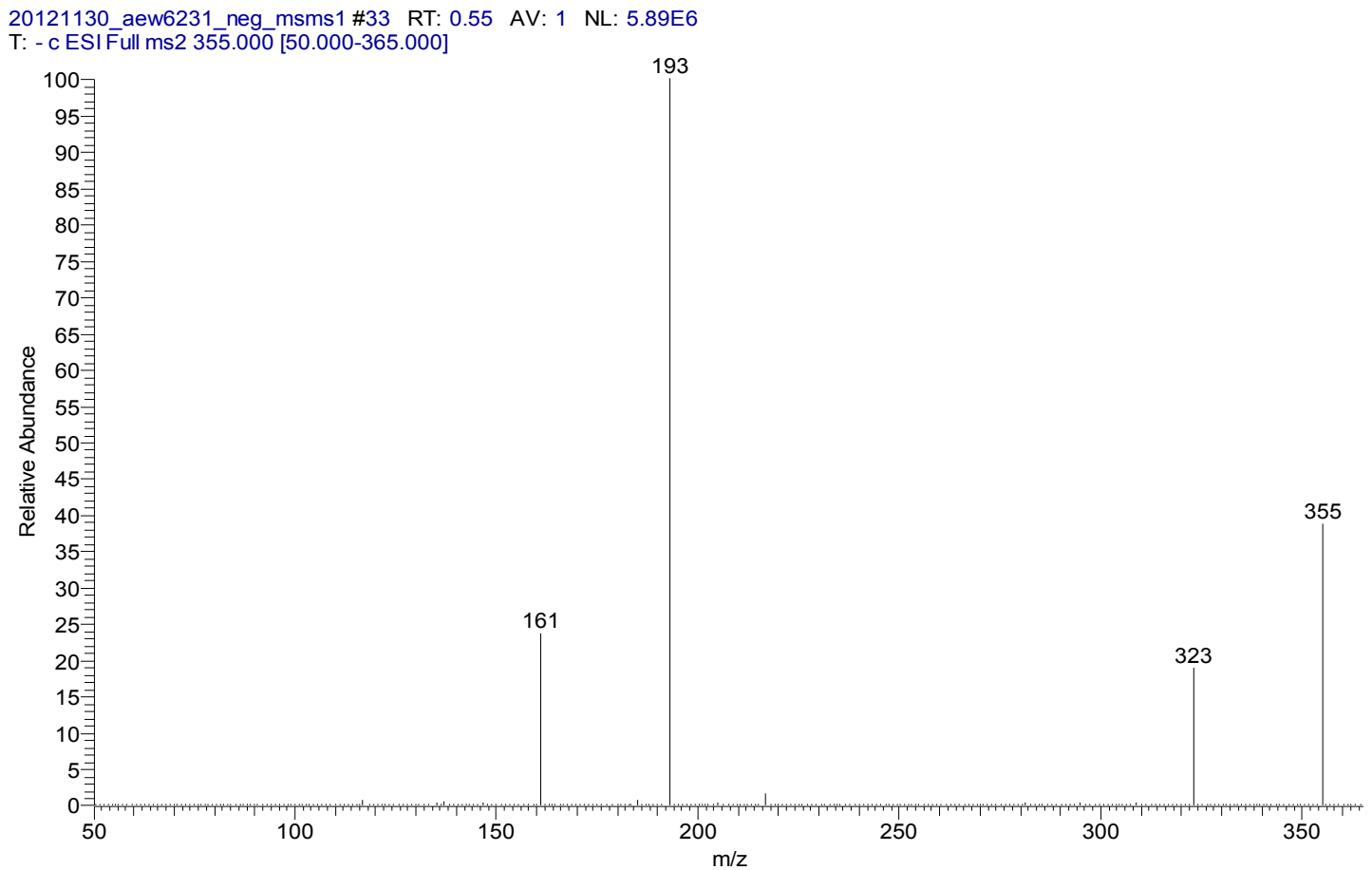

Compound $\mathbf{5}$ was afforded as optically active white amorphous powder with the assistance of conventional chromatographic methods. It possessed a molecular formula $\mathrm{C}_{14} \mathrm{H}_{18} \mathrm{O}_{8}$ deduced from the HR-ESI-MS ( $m / z 337.0897[\mathrm{M}+\mathrm{H}]^{+}$, calcd 337.0899). The IR spectrum showed the absorption bands at 3409 and $1628 \mathrm{~cm}^{-1}$ attributed to the presence of hydroxyl and conjugated carbonyl groups. The ${ }^{1} \mathrm{H}$ NMR spectrum (Table 2) of 5 displayed a broad hydroxyl group at $\delta 13.0(1 \mathrm{H}$, br s), three mutually coupled aromatic protons signals at $\delta 6.55(1 \mathrm{H}, \mathrm{dd}, J=8.4,1.2 \mathrm{~Hz}), 6.75(1 \mathrm{H}, \mathrm{dd}, J=8.4,1.2 \mathrm{~Hz})$ and $7.38(1 \mathrm{H}, \mathrm{dd}, J=8.4,8.4 \mathrm{~Hz})$, and one methyl singlet at $\delta 2.77(3 \mathrm{H})$. In addition, the HMQC correlation between the methyl singlet $(\delta 2.77)$ and a deshielded carbon at $\delta 33.8$ suggested it to be an acetyl group. Moreover, an anomeric proton at $\delta 5.12(1 \mathrm{H}, \mathrm{d}, J=8.8 \mathrm{~Hz})$, together with a set of signals arising from a sugar moiety at $\delta 101.2,77.3,77.1,73.6,70.2$ and 61.6 in its ${ }^{13} \mathrm{C}$ NMR spectrum, revealed the presence of one glucose fragment. Acidic hydrolysis of compound 5 liberated D-glucose which was determined by comparison with the authentic sample with HPLC method. The locations of the glucosyl, acetyl and hydroxyl groups were determined by 2D spectral experiments. In the HMBC spectrum (Figure 2$)$ of $\mathbf{5}$, the methyl protons $(\delta 2.77)$ and the anomeric proton $(\delta 5.12)$ were correlated with C-1 $(\delta 111.8)$ and C-2 $(\delta 159.5)$, respectively. Furthermore, the NOESY correlation of anomeric proton $(\delta 5.12)$ with $\mathrm{H}-3(\delta 6.75)$ confirmed the structure of $\mathbf{5}$. Compound $\mathbf{5}$ was therefore determined 
to be 2',6'-dihydroxyacetophenone 2'-O- $\beta$-D-glucopyranoside. It has previously only been prepared by synthesis [17] and is reported herein from nature for the first time.

\subsection{Anti-Inflammatory Activity}

Inflammation is related to morbidity and mortality of many diseases and is recognized as part of the complex biological response of vascular tissues to harmful stimuli. It is the host response to infection or injury, which involves the recruitment of leukocytes and the release of inflammatory mediators, including nitric oxide (NO). NO is the metabolic by-product of the conversion of L-arginine to L-citrulline by a class of enzymes termed NO synthases (NOS). Numerous cytokines can induce the transcription of inducible NO synthase (iNOS) in leukocytes, fibroblasts, and other cell types, accounting for enhanced levels of NO. In the experimental model of acute inflammation, inhibition of iNOS can have a dose-dependent protective effect, suggesting that NO promotes edema and vascular permeability. NO also has a detrimental effect in chronic models of arthritis, whereas protection is seen with iNOS inhibitors. The iNOS inhibiting potentials of 1-2 and 6-19 were evaluated by examining their effects on LPS-induced iNOS-dependent NO production in RAW 264.7 cells determined by MTT assays. Cells cultured with 1-2 and 6-19 at different concentrations except 18 (at $42 \mu \mathrm{M}$ ) used in the presence of $100 \mathrm{ng} / \mathrm{mL}$ LPS for $24 \mathrm{~h}$ did not change cell viability thus the NO inhibiting effects may not due to the cytotoxicity (Table 3 ). In the examined concentration ranges $(5.25-74 \mu \mathrm{M})$, NO production decreased in the presence of 1-2 and 6-19 in a dose-dependent manner (Table 3). Flavonoids are widely distributed in the higher plants capable of modulating the activity of enzymes and affect the behavior of many cell systems, including NO inhibitory activity. The structure-activity relationships of 3',4'-oxygenated flavones were discussed by Matsuda [53] and Kim et al. [54]. In 1999, Kim et al. [54] examined the naturally occurred flavonoids for NO production inhibitory activity in LPS-activated RAW 264.7 cells and the following structural requirements were afforded: (a) the strongly active flavonoids possessed the $\mathrm{C} 2-\mathrm{C} 3$ double bond and 5,7-dihydroxyl groups; (b) the 8-methoxyl group and 4'- or 3',4'-vicinal substitutions favorably affected inhibitory activity; (c) the 2',4'-(meta)-hydroxyl substitutions abolished the inhibitory activity; (d) the 3-hydroxyl moiety reduced the activity; (e) flavonoid glycosides were not active regardless of the types of aglycones. Andrographis species are noted for profuse production of 2'-oxygenated flavones and in the present study, the bioactive data of the examined flavonoids using RAW 264.7 cells were in agreement with the previous report by Kim et al., and the additional structural requirements of flavonoids for NO production inhibitory activity were suggested as follows: (1) the glycosidic moiety reduced the activity, like 9 and 14; (2) the 2'-hydroxyl group did not cause significant effects on NO inhibitory activity; (3) methylation of 5-hydroxyl group enhanced the activity, like 13 and 14 (Table 4). The structure-activity relationships of flavonoids for NO production inhibitory activity resulted from our study clarified the insufficiency in the previous report. 
Table 3. Effects of 1-2 and 6-19 on lipopolysaccharide (LPS)-induced cell viability and NO production of RAW 264.7 macrophages $\|$.

\begin{tabular}{|c|c|c|c|c|c|}
\hline & Dose $(\mu \mathrm{M})$ & $\begin{array}{l}\text { Cell viability } \\
\text { (\% of control) }\end{array}$ & NO level & $\begin{array}{l}\text { NO inhibition } \\
\text { (\% of control) }\end{array}$ & $\mathrm{IC}_{50}(\boldsymbol{\mu M})$ \\
\hline control & $(-)$ & $100.0 \pm 3.3$ & $0.2 \pm 0.9$ & $(-)$ & \\
\hline LPS & $(+)$ & $96.9 \pm 6.1$ & $59.4 \pm 0.8^{\# \# \#}$ & $(-)$ & \\
\hline \multirow[t]{4}{*}{1} & 5.25 & $92.1 \pm 4.2$ & $48.1 \pm 1.5$ & $19.0 \pm 2.5$ & $>42$ \\
\hline & 10.5 & $86.6 \pm 1.5$ & $48.1 \pm 1.7$ & $19.1 \pm 2.9$ & \\
\hline & 21 & $83.9 \pm 3.5$ & $45.3 \pm 1.4$ & $23.7 \pm 2.3$ & \\
\hline & 42 & $80.1 \pm 3.7$ & $42.7 \pm 1.1 *$ & $28.1 \pm 1.8$ & \\
\hline \multirow[t]{4}{*}{2} & 5.63 & $103.6 \pm 2.3$ & $49.8 \pm 4.6$ & $16.1 \pm 7.7$ & $>45$ \\
\hline & 11.25 & $99.2 \pm 6.8$ & $46.2 \pm 2.5$ & $22.2 \pm 4.2$ & \\
\hline & 22.5 & $99.2 \pm 4.2$ & $41.8 \pm 1.6^{*}$ & $29.6 \pm 2.7$ & \\
\hline & 45 & $99.8 \pm 6.0$ & $39.9 \pm 0.7 * *$ & $32.8 \pm 1.1$ & \\
\hline \multirow[t]{4}{*}{6} & 5.63 & $92.6 \pm 3.0$ & $45.0 \pm 2.7$ & $24.2 \pm 4.6$ & $>45$ \\
\hline & 11.25 & $85.7 \pm 4.6$ & $46.2 \pm 1.8$ & $22.3 \pm 3.0$ & \\
\hline & 22.5 & $84.6 \pm 3.5$ & $44.4 \pm 2.1 *$ & $25.2 \pm 3.5$ & \\
\hline & 45 & $81.4 \pm 2.1$ & $43.2 \pm 1.8 *$ & $27.2 \pm 3.0$ & \\
\hline \multirow[t]{4}{*}{7} & 8.75 & $90.5 \pm 4.0$ & $45.2 \pm 1.2$ & $23.9 \pm 2.0$ & $>70$ \\
\hline & 17.5 & $88.2 \pm 1.7$ & $44.6 \pm 2.6$ & $25.0 \pm 4.3$ & \\
\hline & 35 & $84.9 \pm 2.2$ & $43.8 \pm 2.1 *$ & $26.2 \pm 3.5$ & \\
\hline & 70 & $83.2 \pm 5.6$ & $43.5 \pm 2.7 *$ & $26.8 \pm 4.6$ & \\
\hline \multirow[t]{4}{*}{8} & 9.25 & $90.1 \pm 7.0$ & $51.7 \pm 1.9$ & $12.9 \pm 3.2$ & $>74$ \\
\hline & 18.5 & $86.4 \pm 6.5$ & $47.2 \pm 2.1$ & $20.5 \pm 3.6$ & \\
\hline & 37 & $82.0 \pm 4.4$ & $47.1 \pm 1.8$ & $20.7 \pm 3.1$ & \\
\hline & 74 & $79.3 \pm 1.7$ & $42.2 \pm 2.5 *$ & $28.9 \pm 4.1$ & \\
\hline \multirow[t]{4}{*}{9} & 5.5 & $89.7 \pm 2.7$ & $42.7 \pm 4.0 *$ & $28.1 \pm 6.8$ & $>44$ \\
\hline & 11 & $84.8 \pm 1.8$ & $41.1 \pm 1.6 *$ & $30.8 \pm 2.7$ & \\
\hline & 22 & $83.4 \pm 1.9$ & $38.7 \pm 3.0 * *$ & $34.8 \pm 5.0$ & \\
\hline & 44 & $80.2 \pm 1.7$ & $38.3 \pm 2.0 * *$ & $35.6 \pm 3.3$ & \\
\hline \multirow[t]{4}{*}{10} & 8.75 & $89.4 \pm 8.3$ & $41.3 \pm 1.3$ & $30.4 \pm 2.3$ & $37.6 \pm 1.2$ \\
\hline & 17.5 & $84.9 \pm 2.0$ & $39.6 \pm 1.5 * *$ & $33.3 \pm 2.5$ & \\
\hline & 35 & $82.1 \pm 3.7$ & $30.7 \pm 1.5 * *$ & $48.3 \pm 2.6$ & \\
\hline & 70 & $80.1 \pm 2.9$ & $21.2 \pm 2.7 * * *$ & $64.2 \pm 4.5$ & \\
\hline \multirow[t]{4}{*}{11} & 5.75 & $98.9 \pm 4.4$ & $50.6 \pm 0.6$ & $14.9 \pm 1.0$ & $>46$ \\
\hline & 11.5 & $96.2 \pm 4.2$ & $47.5 \pm 4.0$ & $20.0 \pm 6.7$ & \\
\hline & 23 & $96.5 \pm 4.5$ & $46.7 \pm 0.9$ & $21.4 \pm 1.4$ & \\
\hline & 46 & $93.0 \pm 3.4$ & $46.5 \pm 1.9$ & $21.7 \pm 3.2$ & \\
\hline \multirow[t]{4}{*}{12} & 8 & $100 \pm 5.4$ & $50.0 \pm 2.3$ & $15.8 \pm 3.9$ & $>64$ \\
\hline & 16 & $96.5 \pm 9.2$ & $49.5 \pm 1.0$ & $16.7 \pm 1.7$ & \\
\hline & 32 & $96.3 \pm 4.2$ & $48.0 \pm 1.0$ & $19.2 \pm 1.6$ & \\
\hline & 64 & $94.3 \pm 2.1$ & $45.5 \pm 2.0$ & $23.4 \pm 3.4$ & \\
\hline \multirow[t]{4}{*}{13} & 8.5 & $98.1 \pm 6.6$ & $52.2 \pm 1.3$ & $12.1 \pm 2.2$ & $>68$ \\
\hline & 17 & $97.7 \pm 1.7$ & $48.8 \pm 0.7$ & $17.8 \pm 1.3$ & \\
\hline & 34 & $90.8 \pm 2.9$ & $47.9 \pm 3.9$ & $19.4 \pm 6.6$ & \\
\hline & 68 & $90.8 \pm 8.5$ & $47.5 \pm 1.0$ & $20.1 \pm 1.7$ & \\
\hline
\end{tabular}


Table 3. Cont.

\begin{tabular}{|c|c|c|c|c|c|}
\hline & Dose $(\mu \mathrm{M})$ & $\begin{array}{l}\text { Cell viability } \\
\text { (\% of control) }\end{array}$ & NO level & $\begin{array}{l}\text { NO inhibition } \\
\text { (\% of control) }\end{array}$ & $\mathrm{IC}_{50}(\boldsymbol{\mu M})$ \\
\hline \multirow[t]{4}{*}{14} & 8 & $98.9 \pm 3.5$ & $40.8 \pm 2.7 *$ & $31.4 \pm 4.5$ & $39.1 \pm 1.3$ \\
\hline & 16 & $97.9 \pm 3.8$ & $34.3 \pm 2.0 * *$ & $42.3 \pm 3.4$ & \\
\hline & 32 & $94.3 \pm 4.6$ & $32.2 \pm 1.5 * *$ & $45.8 \pm 7.5$ & \\
\hline & 64 & $92.2 \pm 3.2$ & $23.1 \pm 2.3 * * *$ & $61.1 \pm 3.8$ & \\
\hline \multirow[t]{4}{*}{15} & 7.5 & $99.4 \pm 4.3$ & $45.6 \pm 1.1$ & $23.3 \pm 1.8$ & $>60$ \\
\hline & 15 & $99.2 \pm 2.9$ & $43.0 \pm 3.5 *$ & $27.7 \pm 5.9$ & \\
\hline & 30 & $98.9 \pm 1.8$ & $42.0 \pm 4.0 *$ & $29.3 \pm 6.7$ & \\
\hline & 60 & $98.8 \pm 6.9$ & $41.2 \pm 1.9 *$ & $30.6 \pm 3.1$ & \\
\hline \multirow[t]{4}{*}{16} & 8.5 & $101.5 \pm 4.3$ & $56.5 \pm 2.0$ & $4.9 \pm 3.4$ & $>68$ \\
\hline & 17 & $100.3 \pm 1.0$ & $51.7 \pm 2.6$ & $13.0 \pm 4.4$ & \\
\hline & 34 & $99.6 \pm 1.0$ & $50.4 \pm 4.6$ & $15.1 \pm 7.8$ & \\
\hline & 68 & $93.7 \pm 0.9$ & $44.6 \pm 0.5 *$ & $24.9 \pm 0.9$ & \\
\hline \multirow[t]{4}{*}{17} & 5.63 & $100.8 \pm 0.8$ & $52.4 \pm 2.9$ & $11.8 \pm 4.9$ & $>45$ \\
\hline & 11.25 & $98.8 \pm 3.5$ & $51.7 \pm 4.6$ & $12.9 \pm 7.7$ & \\
\hline & 22.5 & $97.8 \pm 3.6$ & $50.8 \pm 3.8$ & $14.5 \pm 6.4$ & \\
\hline & 45 & $98.3 \pm 1.9$ & $46.4 \pm 4.0$ & $21.8 \pm 6.7$ & \\
\hline \multirow[t]{4}{*}{18} & 5.25 & $101.4 \pm 1.2$ & $53.5 \pm 4.4$ & $9.9 \pm 7.4$ & $>42$ \\
\hline & 10.5 & $100.5 \pm 1.8$ & $52.1 \pm 3.7$ & $12.3 \pm 6.2$ & \\
\hline & 21 & $95.6 \pm 0.8$ & $50.7 \pm 4.5$ & $14.6 \pm 7.6$ & \\
\hline & 42 & $74.1 \pm 6.6$ & $(-)$ & $(-)$ & \\
\hline \multirow[t]{4}{*}{19} & 9.25 & $103.5 \pm 4.8$ & $52.7 \pm 4.7$ & $11.2 \pm 8.0$ & $>74$ \\
\hline & 18.5 & $98.2 \pm 11.3$ & $47.5 \pm 4.8$ & $20.1 \pm 8.0$ & \\
\hline & 37 & $92.9 \pm 7.6$ & $46.7 \pm 4.0$ & $21.4 \pm 6.8$ & \\
\hline & 74 & $81.6 \pm 6.5$ & $44.4 \pm 2.8 *$ & $25.2 \pm 4.7$ & \\
\hline
\end{tabular}

$\|$ The data were presented as mean \pm S.D. for three different experiments performed in triplicate. ${ }^{\# \prime \prime}$ compared with sample of control group. ${ }^{*} p<0.05,{ }^{* *} p<0.01$, and ${ }^{* * *} p<0.001$ were compared with LPS-alone group.

Table 4. Effects of flavones and flavanones on NO production inhibitory activity in LPS-activated mouse peritoneal macrophages.<smiles>[R]c1cc([R])c2c(c1)OC(c1ccccc1[R])CC2=O</smiles>

\begin{tabular}{ccccccccccc} 
& $\mathbf{R}_{\mathbf{1}}$ & $\mathbf{R}_{\mathbf{2}}$ & $\mathbf{R}_{\mathbf{3}}$ & $\mathbf{R}_{\mathbf{4}}$ & $\mathbf{I C}_{\mathbf{5 0}}(\boldsymbol{\mu} \mathbf{M})$ & & $\mathbf{R}_{\mathbf{1}}$ & $\mathbf{R}_{\mathbf{2}}$ & $\mathbf{R}_{\mathbf{3}}$ & $\mathbf{I C}_{\mathbf{5 0}}(\boldsymbol{\mu} \mathbf{M})$ \\
\hline $\mathbf{1}$ & $\mathrm{OGlc}$ & $\mathrm{OCH}_{3}$ & $\mathrm{OH}$ & $\mathrm{OH}$ & $>42$ & $\mathbf{2}$ & $\mathrm{OGlc}$ & $\mathrm{OCH}_{3}$ & $\mathrm{OH}$ & $>45$ \\
$\mathbf{6}$ & $\mathrm{OGlc}$ & $\mathrm{OCH}_{3}$ & $\mathrm{H}$ & $\mathrm{OH}$ & $>45$ & $\mathbf{8}$ & $\mathrm{OH}$ & $\mathrm{OCH}_{3}$ & $\mathrm{H}$ & $>74$ \\
$\mathbf{7}$ & $\mathrm{OH}$ & $\mathrm{OCH}_{3}$ & $\mathrm{H}$ & $\mathrm{OH}$ & $>70$ & $\mathbf{1 0}$ & $\mathrm{OH}$ & $\mathrm{OCH}_{3}$ & $\mathrm{OH}$ & $37.6 \pm 1.2^{\mathrm{b}}$ \\
$\mathbf{9}$ & $\mathrm{OGlc}$ & $\mathrm{OCH}_{3}$ & $\mathrm{OCH}_{3}$ & $\mathrm{H}$ & $>44$ & & & & & \\
$\mathbf{1 1}$ & $\mathrm{OGlc}$ & $\mathrm{OCH}_{3}$ & $\mathrm{H}$ & $\mathrm{H}$ & $>46$ & & & & & \\
$\mathbf{1 3}$ & $\mathrm{OH}$ & $\mathrm{OCH}_{3}$ & $\mathrm{OCH}_{3}$ & $\mathrm{H}$ & $>64$ & & & & & \\
$\mathbf{1 4}$ & $\mathrm{OCH}$ & $\mathrm{OCH}_{3}$ & $\mathrm{OCH}_{3}$ & $\mathrm{H}$ & $39.1 \pm 1.3^{\mathrm{a}}$ & & & & & \\
$\mathbf{1 5}$ & $\mathrm{OH}$ & $\mathrm{OCH}_{3}$ & $\mathrm{OCH}_{3}$ & $\mathrm{OCH}_{3}$ & $>60$ & & & & & \\
$\mathbf{1 8}$ & $\mathrm{OH}$ & $\mathrm{OCH}_{3}$ & $\mathrm{OCH}_{3}$ & $\mathrm{OGlc}$ & $>42$ & & & & & \\
$\mathbf{1 9}$ & $\mathrm{OH}$ & $\mathrm{OCH}_{3}$ & $\mathrm{H}$ & $\mathrm{H}$ & $>74$ & & & & & \\
\hline
\end{tabular}

Glc, $\beta$-D-glucopyranosyl; ${ }^{a}$ Values in parentheses represent the inhibition (\%) at $8 \mu \mathrm{M} ;{ }^{\mathrm{b}}$ Values in parentheses represent the inhibition (\%) at $8.75 \mu \mathrm{M}$. 


\section{Experimental Section}

\subsection{General}

The UV spectra were obtained with Hitachi UV-3210 spectrophotometer. The IR spectra were measured with a Shimadzu FTIR Prestige-21 spectrometer. Optical rotations were recorded with a Jasco DIP-370 digital polarimeter in a $0.5 \mathrm{dm}$ cell. The ESIMS and HRESIMS were taken on a Bruker Daltonics APEX II 30e spectrometer. The FABMS and HRFABMS were taken on a Jeol JMS-700 spectrometer. The ESIMS (negative ESI) data were measured using a Thermo TSQ Quantum Ultra LC/MS/MS spectrometer. The ${ }^{1} \mathrm{H}$ and ${ }^{13} \mathrm{C}$ NMR spectrums were measured by Bruker Avance 300, 400 and AV-500 NMR spectrometers with TMS as the internal reference, and chemical shifts are expressed in $\delta$ (ppm). The CD spectrum was recorded in a Jasco J-720 spectrometer. Sephadex LH-20, silica gel (70-230 and 230-400 mesh; Merck, Darmstadt, Germany) and reversed-phase silica gel (RP-18; particle size 20-40 $\mu \mathrm{m}$; Silicycle) were used for column chromatography, and silica gel $60 \mathrm{~F}_{254}$ (Merck, Darmstadt, Germany) and RP-18 $\mathrm{F}_{254 \mathrm{~S}}$ (Merck, Darmstadt, Germany) were used for TLC. HPLC was performed on a Shimadzu LC-10AT $\mathrm{VP}_{\mathrm{V}}$ (Tokyo, Japan) system equipped with a Shimadzu SPD-M20A diode array detector at $250 \mathrm{~nm}$, a Purospher STAR RP-8e column $(5 \mu \mathrm{m}, 250 \times 4.6 \mathrm{~mm})$ and Cosmosil 5C $\mathrm{C}_{18}$ ARII $(250 \times 4.6 \mathrm{~mm}$ i.d. Nacalai Tesque Inc.) (Tokyo, Japan). LPS (endotoxin from Escherichia coli, serotype 0127:B8), MTT (3-[4,5-dimethylthiazol-2-yl]-2,5-diphenyltetrazolium bromide) and other chemicals were purchased from Sigma Chemical Co. (St. Louis, MO, USA).

\subsection{Plant Materials}

The whole plant of $A$. echioides Nees was collected from Tirupati, Andhra Pradesh, India in May 1998. The plant was authenticated by Professor C. S. Kuoh, Department of Life Science, National Cheng Kung University, Taiwan. The voucher specimens (DG-199) have been deposited in the herbarium of the Department of Botany, Sri Venkateswara University, Tirupati, India; and Department of Chemistry, National Cheng Kung University, Tainan, Taiwan, respectively.

\subsection{Extraction and Isolation}

The plant materials $(10 \mathrm{~kg})$ were cut into small pieces and heated at refluxed with $85 \%$ aqueous $\mathrm{MeOH}(5 \times 80 \mathrm{~L})$. The resulting $\mathrm{MeOH}$ extract $(704 \mathrm{~g})$ was partitioned between $\mathrm{CHCl}_{3}$ and $\mathrm{H}_{2} \mathrm{O}$ (each $3 \mathrm{~L}$ ) for five times to yield the $\mathrm{CHCl}_{3}$ layer $\left(208 \mathrm{~g}\right.$ ) and $\mathrm{H}_{2} \mathrm{O}$ layer $\left(446 \mathrm{~g}\right.$ ). The $\mathrm{CHCl}_{3}$ layer was subjected to silica gel column chromatography (CC) using a gradient mixture of $\mathrm{CHCl}_{3}-\mathrm{MeOH}(19: 1$, 9:1, 7:1, 5:1, 3:1, 1:1) as eluent to give 11 fractions (Fr. 1-11). Fr. 2 was purified by CC over silica gel ( $n$-hexane-diisopropyl, ether 40:1) to yield squalene (74.6 mg). Fr. 4 was separated by CC over silica gel ( $n$-hexane-acetone, 49:1) to yield pinostrobin (67.2 mg). Fr. 5 was subjected to chromatography on silica gel ( $n$-hexane-EtOAc, 9:1) to yield tectochrysin $(20.3 \mathrm{mg})$. Fr. 6 was chromatographed over silica gel ( $n$-hexane-acetone, 3:1) to yield dihydroechioidinin $(11.2 \mathrm{mg})$, tectochrysin $(111.9 \mathrm{mg})$ and skullcapflavone I 2'-methyl ether $(76.7 \mathrm{mg})$. Fr. 7 was purified by CC over silica gel ( $n$-hexane-acetone, 3:1) to yield eight fractions: 7.1, 7.2, 7.3, 7.4, 7.5, 7.6, 7.7 and 7.8. Fr. 7.3 was chromatographed over silica gel (n-hexane-acetone, 3:1) to yield 7,8-dimethoxy-5-hydroxyflavone (35.8 $\mathrm{mg}$ ), 
5,7,2'-trimethoxyflavone $(6.5 \mathrm{mg})$ and echioidinin $(6.3 \mathrm{mg})$. Fr. 7.4 was chromatographed over silica gel ( $n$-hexane-diisopropyl ether, 3:1) to yield skullcapflavone I $(6.2 \mathrm{mg})$ and dihydroechioidinin $(1.2 \mathrm{mg})$. Fr. 7.5 was chromatographed over silica gel ( $n$-hexane-EtOAc, $3: 1)$ to yield $\beta$-sitosterol (33.2 mg), androgechoside B (1.3 mg), tectochrysin (12.3 mg), 5,7,8-trimethoxyflavone (30.7 mg) and 5,7-dimethoxyflavone (7.6 mg). Fr. 7.6 was chromatographed over silica gel ( $n$-hexane-EtOAc, 2:1) to yield 4-hydroxy-3-methoxy-trans-cinnamic acid methyl ester $(5.6 \mathrm{mg})$, 4-hydroxybenzaldehyde $(7.2 \mathrm{mg})$ and $13^{2}$-hydroxy-(132-R)-phaeophytin $(2.4 \mathrm{mg})$. Fr. 7.7 was chromatographed over silica gel $\left(\mathrm{CHCl}_{3}\right.$-acetone, 29:1) to yield $(E)$-phytyl epoxide $(11.5 \mathrm{mg})$, phytol $(27.9 \mathrm{mg})$, dehydrovomifoliol $(5.3 \mathrm{mg})$ and $3 \beta$-hydroxy-5 $\alpha, 6 \alpha$-epoxy-7-megastigmen-9-one $(5.1 \mathrm{mg})$. Fr. 7.8 was chromatographed over silica gel $\left(\mathrm{CHCl}_{3}-\mathrm{MeOH}, 39: 1\right)$ to yield $1 \mathrm{H}$-indole-3-carbaldehyde (2.3 mg), loliolide (10.1 mg) and phytene 1,2-diol (11.5 mg). Fr. 8 was chromatographed over silica gel $\left(\mathrm{CHCl}_{3}-\mathrm{MeOH}, 7: 1\right)$ to yield 7,8-dimethoxy-5-hydorxyflavone (3.3 mg), skullcapflavone I 2'-O- $\beta$-D-glucopyranoside (4.5 mg), echioidinin 5-O- $\beta$-D-glucopyranoside $(1.2 \mathrm{mg})$, dihydroechioidinin $(677.6 \mathrm{mg})$, androechin $(7.3 \mathrm{mg})$, androgechoside B $(7.9 \mathrm{mg})$ and tectochrysin 5-glucoside $(5.0 \mathrm{mg})$. Fr. 9 was chromatographed over silica gel (EtOAc- $\mathrm{MeOH}, 9: 1)$ to yield andrographidine $\mathrm{E}(10.1 \mathrm{mg})$, androechin $(1.2 \mathrm{mg})$ and $\beta$-sitosteryl-3-O- $\beta$-glucopyranoside $(25.3 \mathrm{mg})$. Fr. 10 was separated by $\mathrm{CC}$ over silica gel $\left(\mathrm{CHCl}_{3}-\mathrm{MeOH}\right.$, $5: 1)$ to yield echioidin $(5.1 \mathrm{mg})$, androgechoside $\mathrm{B}(0.5 \mathrm{mg})$, negletein $6-O-\beta$-D-glucopyranoside (3.8 $\mathrm{mg})$, androgechoside A (34.7 mg) and 4-hydorxy-trans-cinnamic acid methyl ester (4.0 mg).

The $\mathrm{H}_{2} \mathrm{O}$ layer (446 g) was separated on Diaion $\mathrm{HP}-20(0 \%-100 \% \mathrm{MeOH})$ to yield seven fractions. Fr. 3 was purified by CC over Sephadex LH-20 $(0 \%-100 \% \mathrm{MeOH})$ to yield 2,6-dihydroxybenzoic acid $(8.2 \mathrm{mg})$. Fr. 4 was subjected to $\mathrm{CC}$ over Sephadex LH-20 $(0 \%-100 \% \mathrm{MeOH})$ to yield $O$-coumaric acid $(3.4 \mathrm{mg})$. Fr. 5 was separated on Sephadex LH-20 $(0 \%-100 \% \mathrm{MeOH})$ to yield androechioside B (18.9 mg) and androechioside D (12.0 mg). Fr. 6 was separated on Sephadex LH-20 $(0 \%-100 \% \mathrm{MeOH})$ to yield methyl salicylate glucoside $(2.1 \mathrm{mg})$, androechioside A $(3.4 \mathrm{mg})$ and acetophenone-2-O- $\beta$-D-glucopyranoside $(17.0 \mathrm{mg})$. Fr. 7 was subjected to CC over Sephadex LH-20 $(0 \%-100 \% \mathrm{MeOH})$ to yield andrographidine $\mathrm{C}(26.9 \mathrm{mg})$, echioidinin 5-O- $\beta$-D-glucopyranoside $(3.2 \mathrm{mg})$ and androechin $(0.9 \mathrm{mg})$.

\subsubsection{Androgechoside A (1)}

White amorphous powder; $[\alpha]_{\mathrm{D}}^{25}-166.7(c 0.04, \mathrm{MeOH}) ; \mathrm{UV}(\mathrm{MeOH}), \lambda_{\max }(\log \varepsilon) 328(3.61), 271$, (3.92), 224 (3.75), 207 (4.05) nm; IR (KBr) $v_{\max } 3368,1628,1573,1076,1049 \mathrm{~cm}^{-1} ;{ }^{1} \mathrm{H}$ and ${ }^{13} \mathrm{C}$ NMR see Table 1; FABMS (positive mode) $m / z$ (rel. int.): $463[\mathrm{M}+\mathrm{H}]^{+}$; HRFABMS $m / z: 462.1159[\mathrm{M}]^{+}$.

\subsubsection{Androgechoside B (2)}

White amorphous powder; $[\alpha]_{\mathrm{D}}^{25}-149.2$ (c 0.02, MeOH); UV (MeOH), $\lambda_{\max }(\log \varepsilon) 383(3.83), 280$ (4.38), 211 (4.53), 204 (4.57) nm; CD (MeOH): nm $\lambda_{\max }(\Delta \varepsilon) 337$ (-4.92), 275 (+15.5); IR (KBr) $v_{\max }$ 3373, 1609, 1272, 1070, $1034 \mathrm{~cm}^{-1} ;{ }^{1} \mathrm{H}$ and ${ }^{13} \mathrm{C}$ NMR see Table 1; FABMS (positive mode) $\mathrm{m} / \mathrm{z}$ (rel. int.): $449[\mathrm{M}+\mathrm{H}]^{+}$; HRFABMS $m / z$ : $449.1449[\mathrm{M}+\mathrm{H}]^{+}$(calcd 449.1448). 


\subsubsection{Androechioside A (3)}

White amorphous powder; $[\alpha]_{\mathrm{D}}^{25}+4.5$ (c 0.68, MeOH); UV (MeOH), $\lambda_{\max }(\log \varepsilon) 263(3.26), 218$ (3.45), 203 (3.84); IR (KBr) $v_{\max } 3449,1652,1615,1514,1327,1160,1072 \mathrm{~cm}^{-1} ;{ }^{1} \mathrm{H}$ and ${ }^{13} \mathrm{C}$ NMR see Table 2; ESIMS m/z (rel. int.): $383[\mathrm{M}+\mathrm{Na}]^{+}$; HRESIMS $\mathrm{m} / z: 383.0952[\mathrm{M}+\mathrm{Na}]^{+}$(calcd for $\left.\mathrm{C}_{15} \mathrm{H}_{20} \mathrm{O}_{10} \mathrm{Na}, 383.0954\right)$.

\subsubsection{Androechioside B (4)}

White amorphous powder; $[\alpha]_{\mathrm{D}}^{25}-27.8$ (c 0.34, MeOH); UV (MeOH), $\lambda_{\max }(\log \varepsilon) 301(3.83), 246$ (4.10), 210 (4.23) nm; IR (KBr) $v_{\max } 3381,1731,1672,1598,1231,1072 \mathrm{~cm}^{-1}$; ${ }^{1} \mathrm{H}$ and ${ }^{13} \mathrm{C}$ NMR see Table 2; ESIMS $m / z$ (rel. int.): $379[\mathrm{M}+\mathrm{Na}]^{+}$; HRESIMS $m / z: 379.1007[\mathrm{M}+\mathrm{Na}]^{+}$(calcd for $\left.\mathrm{C}_{16} \mathrm{H}_{20} \mathrm{O}_{9} \mathrm{Na}, 379.1005\right)$.

\subsubsection{2',6'-Dihydroxyacetophenone 2'-O- $\beta$-D-glucopyranoside (5)}

White amorphous powder; $[\alpha]_{\mathrm{D}}^{25}-8.8$ (c 0.12, MeOH); UV (MeOH), $\lambda_{\max }(\log \varepsilon) 331(3.23), 265$ (3.48), 214 (3.61), 209 (4.12) nm; IR (KBr) $v_{\max } 3409,1628,1600,1456,1075 \mathrm{~cm}^{-1} ;{ }^{1} \mathrm{H}$ and ${ }^{13} \mathrm{C} \mathrm{NMR}$ see Table 2; ESIMS $m / z$ (rel. int.): $337[\mathrm{M}+\mathrm{Na}]^{+}$; HRESIMS $\mathrm{m} / z: 337.0897[\mathrm{M}+\mathrm{Na}]^{+}$(calcd for $\left.\mathrm{C}_{14} \mathrm{H}_{18} \mathrm{O}_{8} \mathrm{Na}, 337.0899\right)$.

\subsection{Determination of Aldose Configuration}

Compounds 1-5 (each $0.5 \mathrm{mg}$ ) were hydrolyzed with $0.5 \mathrm{M} \mathrm{HCl}(0.4 \mathrm{~mL})$ in a screw-capped vial at $60{ }^{\circ} \mathrm{C}$ for $1 \mathrm{~h}$. The reaction mixture was neutralized with Amberlite IRA400 and filtered. The filtrates were dried in vacuo, then dissolved in $0.1 \mathrm{~mL}$ of pyridine containing L-cysteine methyl ester $(0.5 \mathrm{mg})$, and reacted at $60{ }^{\circ} \mathrm{C}$ for $1 \mathrm{~h}$. To those mixtures were added a solution of $O$-tolylisothiocyanate in pyridine $(5 \mathrm{mg} / 1 \mathrm{~mL})$ at room temperature for $1 \mathrm{~h}$. Those reaction mixtures were directly analyzed by HPLC (Cosmosil 5C 18 ARII $\left(250 \times 4.6 \mathrm{~mm}\right.$ i.d. Nacalai Tesque Inc., Tokyo, Japan); $20 \% \mathrm{CH}_{3} \mathrm{CN}$ in $50 \mathrm{mM}$ acetate; flow rate $0.8 \mathrm{~mL} / \mathrm{min}$; detection, $250 \mathrm{~nm})$. D-glucose $\left(\mathrm{t}_{R} 40.5 \mathrm{~min}\right)$ was identified as the sugar moieties of 1-5 based on comparisons with authentic samples of D-glucose $\left(t_{R} 40.5 \mathrm{~min}\right)$.

\subsection{Determination of iNOS Inhibitory Effects}

\subsubsection{Cell Culture}

A murine macrophage cell line RAW264.7 (BCRC No. 60001) was purchased from the Bioresources Collection and Research Center (BCRC) of the Food Industry Research and Development Institute (Hsinchu, Taiwan). Cells were cultured in plastic dishes containing Dulbecco's Modified Eagle Medium (DMEM, Sigma, St. Louis, MO, USA) supplemented with $10 \%$ fetal bovine serum (FBS, Sigma, St. Louis, MO, USA) in a $\mathrm{CO}_{2}$ incubator $\left(5 \% \mathrm{CO}_{2}\right.$ in air) at $37{ }^{\circ} \mathrm{C}$ and subcultured every 3 days at a dilution of $1: 5$ using $0.05 \%$ trypsin- $0.02 \%$ EDTA in $\mathrm{Ca}^{2+}-\mathrm{Mg}^{2+}$-free phosphate-buffered saline (DPBS). 


\subsubsection{Cell Viability}

Cells $\left(2 \times 10^{5}\right)$ were cultured in 96-well plate containing DMEM supplemented with $10 \%$ FBS for 1 day to become nearly confluent. Then cells were cultured with samples in the presence of $100 \mathrm{ng} / \mathrm{mL}$ LPS for $24 \mathrm{~h}$. After that, the cells were washed twice with DPBS and incubated with $100 \mu \mathrm{L}$ of $0.5 \mathrm{mg} / \mathrm{mL}$ MTT for $2 \mathrm{~h}$ at $37^{\circ} \mathrm{C}$ testing for cell viability. The medium was then discarded and $100 \mu \mathrm{L}$ dimethyl sulfoxide (DMSO) was added. After 30-min incubation, absorbance at $570 \mathrm{~nm}$ was read using a microplate reader (Molecular Devices, Orleans Drive, Sunnyvale, CA, USA).

\subsubsection{Measurement of Nitric Oxide/Nitrite}

NO production was indirectly assessed by measuring the nitrite levels in the cultured media and serum determined by a colorimetric method based on the Griess reaction [55]. The cells were incubated with a test sample in the presence of LPS $(100 \mathrm{ng} / \mathrm{mL})$ at $37{ }^{\circ} \mathrm{C}$ for $24 \mathrm{~h}$. Then, cells were dispensed into $96-$-well plates, and $100 \mu \mathrm{L}$ of each supernatant was mixed with the same volume of Griess reagent (1\% sulfanilamide, $0.1 \%$ naphthyl ethylenediamine dihydrochloride, and 5\% phosphoric acid) and incubated at room temperature for $10 \mathrm{~min}$, the absorbance was measured at $540 \mathrm{~nm}$ with a Micro-Reader (Molecular Devices, Orleans Drive, Sunnyvale, CA, USA). By using sodium nitrite to generate a standard curve, the concentration of nitrite was measured form absorbance at $540 \mathrm{~nm}$.

\subsubsection{Statistical Analysis}

Experimental results were presented as the mean \pm standard deviation (SD) of three parallel measurements. $\mathrm{IC}_{50}$ values were estimated using a non-linear regression algorithm (SigmaPlot 8.0; SPSS Inc. Chicago, IL, USA). Statistical significance is expressed as $* p<0.05,{ }^{*} p<0.01$, and $* * * p<0.001$.

\section{Conclusions}

In the previous literature, there are four Andrographis species containing diterpenoids such as andrographolide, including A. paniculata, A. affinis, A. lineata, and A. wightiana. In our investigation, the major constituents of the titled plant were flavonoids rather than the crystalline bitter principle analogous to diterpenoids. In the evaluation of NO inhibition activity, compounds $\mathbf{1 0}$ and $\mathbf{1 4}$ were the most effective and the $\mathrm{IC}_{50}$ values were $37.6 \pm 1.2 \mu \mathrm{M}$ and $39.1 \pm 1.3 \mu \mathrm{M}$, respectively. These results suggested that the Andrographis species are valuable sources for the discovery of natural anti-inflammatory lead drugs.

\section{Acknowledgments}

The authors are grateful for financial support from the National Science Council of Republic of China awarded to T.-S. Wu.

\section{Conflict of Interest}

The authors have no conflict of interest. 


\section{References}

1. Kirtikar, K.R.; Basu, B.D. Indian Medicinal Plants; Periodical Experts Book Agency: New Delhi, India, 1975; Volume 3, pp. 1884-1886.

2. Chopra, R.N.; Nayer, S.L.; Chopra, I.C. Glossary of Indian Medicinal Plants; Council of Scientific and Industrial Research: New Delhi, India, 1980; p. 18.

3. Harborne, J.B. The Flavonoids: Advances in Research Since 1986; Chapman and Hall: London, UK, 1994; pp. 280-290.

4. Iinuma, M.; Mizuno, M. Natural occurrence and synthesis of 2'-oxygenated flavones, flavonols, flavanones and chalcones. Phytochemistry 1989, 28, 681-694.

5. Kleipool, R.J.C. Constituents of Andrographis paniculata Nees. Nature 1952, 169, 33-34.

6. Chan, W.R.; Taylor, C.R.; Willis, R.L.; Bodden, R.L. The structure and stereochemistry of neoandrographolide, a diterpene glucoside from Andrographis paniculata Nees. Tetrahedron 1971, 27, 5081-5091.

7. Balmain, A.; Connolly, J.D. Minor diterpenoid constituents of Andrographis paniculata Nees. J. Chem. Soc., Perkin Trans. 1 1973, 1, 1247-1251.

8. Fujita, T.; Fujitani, R.; Takeda, Y.; Takaishi, Y.; Yamada, T.; Kido, M.; Miura, I. On the diterpenoids of Andrographis paniculata: X-ray crystallographic analysis of andrographolide and structure determination of new minor diterpenoids. Chem. Pharm. Bull. 1984, 32, 2117-2125.

9. Matsuda, T.; Kuroyanagi, M.; Sugiyama, S.; Umehara, K.; Ueno, A.; Nishi, K. Cell differentiation-inducing diterpenes from Andrographis paniculata Nees. Chem. Pharm. Bull. 1994, 42, 1216-1225.

10. Reddy, M.K.; Reddy, M.V.; Gunasekar, D.; Murthy, M.M.; Caux, C.; Bodo, B. A flavone and an unusual 23-carbon terpenoid from Andrographis paniculata. Phytochemistry 2003, 62, 1271-1275.

11. Govindachari, T.R.; Parthasarathy, P.C.; Pai, B.R.; Subramaniam, P.S. Andrographis echioides. I. Structure and synthesis of echioidinin. Tetrahedron 1965, 21, 2633-2640.

12. Govindachari, T.R.; Parthasarathy, P.C.; Pai, B.R.; Subramaniam, P.S. Andrographis echioides. II. Structure and synthesis of echoidin. Tetrahedron 1965, 21, 3715-3720.

13. Jayaprakasam, B.; Damu, A.G.; Gunasekar, D.; Blond, A.; Bodo, B. Dihydroechioidinin, a flavanone from Andrographis echioides. Phytochemistry 1999, 52, 935-937.

14. Jayaprakasam, B.; Gunasekar, D.; Rao, K.V.; Blond, A.; Bodo, B. Androechin, a new chalcone glucoside from Andrographis echioides. J. Asian Nat. Prod. Res. 2001, 3, 43-48.

15. Rao, Y.K.; Damu, A.G.; Rao, A.J.; Venkatesan, S.; Kuo, P.C.; Rao, C.V.; Wu, T.S. Flavonoids from Andrographis viscosula. Chem. Pharm. Bull. 2003, 51, 1374-1376.

16. Wu, T.S.; Chern, H.J.; Damu, A.G.; Kuo, P.C.; Su, C.R.; Lee, E.J.; Teng, C.M. Flavonoids and ent-labdane diterpenoids from Andrographis paniculata and their antiplatelet aggregatory and vasorelaxing effects. J. Asian Nat. Prod. Res. 2008, 10, 17-24.

17. Gupte, A.; Buolamwini, J.K. Synthesis and biological evaluation of phloridzin analogs as human concentrative nucleoside transporter 3 (hCNT3) inhibitors. Bioorg. Med. Chem. Lett. 2009, 19, 917-921.

18. Chou, T.-H.; Chen, J.-J.; Lee, S.-J.; Chiang, M.Y.; Yang, C.-W.; Chen, I.-S. Cytotoxic flavonoids from the leaves of Cryptocarya chinensis. J. Nat. Prod. 2010, 73, 1470-1475.

19. Kuroyanagi, M.; Sato, M.; Ueno, A.; Nishi, K. Flavonoids from Andrographis paniculata. Chem. Pharm. Bull. 1987, 35, 4429-4435. 
20. Geibel, M.; Geiger, H.; Treutter, D. Tectochrysin 5- and genistein 5-glucosides from the bark of Prunus cerasus. Phytochemistry 1990, 29, 1351-1353.

21. Uchiyama, T.; Miyase, T.; Ueno, A.; Usmanghani, K. Terpenic glycosides from Pluchea indica. Phytochemistry 1989, 28, 3369-3372.

22. Gupta, K.K.; Taneja, S.C.; Dhar, K.L.; Atal, C.K. Flavonoids of Andrographis paniculata. Phytochemistry 1983, 22, 314-315.

23. Mesquita, A.A.L.; Corrêa, D.D.B.; de Pádua, A.P.; Guedes, M.L.O.; Gottlieb, O.R. Flavonoids from four compositae species. Phytochemistry 1986, 25, 1255-1256.

24. Lendl, A.; Werner, I.; Glasl, S.; Kletter, C.; Mucaji, P.; Presser, A.; Reznicek, G.; Jurenitsch, J.; Taylor, D.W. Phenolic and terpenoid compounds from Chione venosa (sw.) urban var. venosa (Bois Bandé). Phytochemistry 2005, 66, 2381-2387.

25. Reddy, B.A.K.; Reddy, M.V.B.; Gunasekar, D.; Murthy, M.M.; Caux, C.; Bodo, B. Two new flavonoids from Andrographis macrobotrys. Indian J. Chem. B 2005, 44B, 1966-1969.

26. Reddy, M.K.; Reddy, M.V.B.; Jayakrishna, G.; Gunasekar, D.; Caux, C.; Bodo, B. Two new flavonoids from Andrographis rothii. Chem. Pharm. Bull. 2003, 51, 191-193.

27. Reddy, M.V.B.; Kishore, P.H.; Rao, C.V.; Gunasekar, D.; Caux, C.; Bodo, B. New 2'-oxygenated flavonoids from Andrographis affinis. J. Nat. Prod. 2003, 66, 295-297.

28. Rao, Y.K.; Fang, S.-H.; Tzeng, Y.-M. Synthesis, growth inhibition, and cell cycle evaluations of novel flavonoid derivatives. Bioorg. Med. Chem. 2005, 13, 6850-6855.

29. Fan, Y.; Xing-Cong, L.; Han-Qing, W.; Chong-Ren, Y. Flavonoid glycosides from Colebrookea oppositifolia. Phytochemistry 1996, 42, 867-869.

30. Wallace, G.; Fry, S.C. In vitro peroxidase-catalysed oxidation of ferulic acid esters. Phytochemistry 1995, 39, 1293-1299.

31. Choy, J.; Jaime-Figueroa, S.; Lara-Jaime, T. A novel practical cleavage of tert-butyl esters and carbonates using fluorinated alcohols. Tetrahedron Lett. 2010, 51, 2244-2246.

32. Machida, K.; Kikuchi, M. Norisoprenoids from Viburnum dilatatum. Phytochemistry 1996, 41, 1333-1336.

33. Reynertson, K.A.; Wallace, A.M.; Adachi, S.; Gil, R.R.; Yang, H.; Basile, M.J.; D’Armiento, J.; Weinstein, I.B.; Kennelly, E.J. Bioactive depsides and anthocyanins from Jaboticaba (Myrciaria cauliflora). J. Nat. Prod. 2006, 69, 1228-1230.

34. Barbosa-Filho, J.M.; Yoshida, M.; Gottlieb, O.R.; de C.S.B.C. Barbosa, R.; Giesbrecht, A.M.; Young, M.C.M. Benzoyl esters and amides, styrylpyrones and neolignans from the fruits of Aniba riparia. Phytochemistry 1987, 26, 2615-2617.

35. Sakdarat, S.; Shuyprom, A.; Pientong, C. Bioactive constituents from the leaves of Clinacanthus nutans Lindau. Biorg. Med. Chem. 2009, 17, 1857-1860.

36. Rajab, M.S.; Cantrell, C.L.; Franzblau, S.G.; Fischer, N.H. Antimycobacterial activity of (E)-phytol and derivatives: A preliminary structure-activity study. Planta medica 1998, 64, 2-4.

37. Brown, G.D. Phytene-1,2-diol from Artemisia annua. Phytochemistry 1994, 36, 1553-1554.

38. Brown, G.D.; Liang, G.-Y.; Sy, L.-K. Terpenoids from the seeds of Artemisia annua. Phytochemistry 2003, 64, 303-323.

39. Heilmann, J.; Müller, E.; Merfort, I. Flavonoid glucosides and dicaffeoylquinic acids from flowerheads of Buphthalmum salicifolium. Phytochemistry 1999, 51, 713-718.

40. Nakabayashi, R.; Kusano, M.; Kobayashi, M.; Tohge, T.; Yonekura-Sakakibara, K.; Kogure, N.; Yamazaki, M.; Kitajima, M.; Saito, K.; Takayama, H. Metabolomics-oriented isolation and 
structure elucidation of 37 compounds including two anthocyanins from Arabidopsis thaliana. Phytochemistry 2009, 70, 1017-1029.

41. Nes, W.D.; Norton, R.A.; Benson, M. Carbon-13 nmr studies on sitosterol biosynthesized from $\left[{ }^{13} \mathrm{C}\right]$ mevalonates. Phytochemistry 1992, 31, 805-811.

42. Chan, H.-H.; Hwang, T.-L.; Reddy, M.V.B.; Li, D.-T.; Qian, K.; Bastow, K.F.; Lee, K.-H.; $\mathrm{Wu}, \mathrm{T} . \mathrm{S}$. Bioactive constituents from the roots of Panax japonicus var. major and development of a LC-MS/MS method for distinguishing between natural and artifactual compounds. J. Nat. Prod. 2011, 74, 796-802.

43. Fan, J.-T.; Kuang, B.; Zeng, G.-Z.; Zhao, S.-M.; Ji, C.-J.; Zhang, Y.-M.; Tan, N.-H. Biologically active arborinane-type triterpenoids and anthraquinones from Rubia yunnanensis. J. Nat. Prod. 2011, 74, 2069-2080.

44. Wu, S.J.; Fotso, S.; Li, F.; Qin, S.; Laatsch, H. Amorphane sesquiterpenes from a Marine Streptomyces sp. J. Nat. Prod. 2007, 70, 304-306.

45. Cheng, S.-Y.; Huang, K.-J.; Wang, S.-K.; Wen, Z.-H.; Chen, P.-W.; Duh, C.-Y. Antiviral and anti-inflammatory metabolites from the soft coral Sinularia capillosa. J. Nat. Prod. 2010, 73, 771-775.

46. Tomimori, T.; Miyaichi, Y.; Imoto, Y.; Kizu, H.; Namba, T. Studies on the nepese crude drugs. VI: On the flavonoid constituents of the root of Scutellaria discolor COLEBR. (2). Chem. Pharm. Bull. 1986, 34, 406-408.

47. Tanaka, T.; Iinuma, M.; Mizuno, M. Spectral properties of 2'-oxygenated flavones. Chem. Pharm. Bull. 1986, 34, 1667-1671.

48. Takagi, S.; Yamaki, M.; Inoue, K. Studies on the water-soluble constituents of the roots of Scutellaria baicalensis GEORGI (Wogon). Yakugaku Zasshi 1980, 100, 1220-1224.

49. Harborne, J.B.; Mabry, T.J. The Flavonoids; Chapman and Hall: London, UK, 1975; pp. 45-77.

50. Matsuda, H.; Nishida, N.; Yoshikawa, M. Antidiabetic principles of natural medicines. V.(1) Aldose reductase inhibitors from Myrcia multiflora DC. (2): Structures of myrciacitrins III, IV, and V. Chem. Pharm. Bull. 2002, 50, 429-431.

51. Gaffield, W. Circular dichroism, optical rotatory dispersion and absolute configuration of flavanones, 3-hydroxyflavanones and their glycosides Tetrahedron 1970, 26, 4093-4108.

52. Tian, L.-W.; Zhang, Y.-J.; Qu, C.; Wang, Y.-F.; Yang, C.-R. Phloroglucinol glycosides from the fresh fruits of Eucalyptus maideni. J. Nat. Prod. 2010, 73, 160-163.

53. Matsuda, H.; Morikawa, T.; Ando, S.; Toguchida, I.; Yoshikawa, M. Structural requirements of flavonoids for nitric oxide production inhibitory activity and mechanism of action. Biorg. Med. Chem. 2003, 11, 1995-2000.

54. Kim, H.K.; Cheon, B.S.; Kim, Y.H.; Kim, S.Y.; Kim, H.P. Effects of naturally occurring flavonoids on nitric oxide production in the macrophage cell Line RAW 264.7 and their structure-activity relationships. Biochem. Pharmacol. 1999, 58, 759-765.

55. Chang, C.-T.; Huang, S.-S.; Lin, S.-S.; Amagaya, S.; Ho, H.-y.; Hou, W.-C.; Shie, P.-H.; $\mathrm{Wu}$, J.-B.; Huang, G.-J. Anti-inflammatory activities of tormentic acid from suspension cells of Eriobotrya Japonica ex vivo and in vivo. Food Chem. 2011, 127, 1131-1137.

(C) 2013 by the authors; licensee MDPI, Basel, Switzerland. This article is an open access article distributed under the terms and conditions of the Creative Commons Attribution license (http://creativecommons.org/licenses/by/3.0/). 